\title{
Nem ortodoxia nem populismo: o Segundo Governo Vargas e a economia brasileira*
}

\section{Pedro Cezar Dutra Fonseca**}

O artigo tem por objeto a economia e as controvérsias sobre a política econômica do Segundo Governo Vargas (1951-1954), bem como de seu significado histórico. Como opção metodológica, parte das diferentes ênfases dadas à implementação da política econômica ao longo do período, as quais são analisadas pari passu às principais correntes que dividem seus analistas e intérpretes.

Palavras-chave: Vargas - Populismo - Nacional-Desenvolvimentismo

Neither Orthodoxy nor Populism: the Second Vargas Administration

This paper analyzes the economy and the controversies surrounding the economic policy in the Second Vargas Administration (1951-1954), as well as its historical significance. As a methodological option, it starts with the different approaches the implementation of the economic policy went through along the period, which are analyzed pari passu with the main studies dividing their analysts and interpreters. Keywords: Vargas - Populism - National-Developmentalism

\footnotetext{
* Artigo recebido e aprovado para publicação em julho de 2009.

** Professor Titular do Departamento de Ciências Econômicas da Universidade Federal do Rio Grande do Sul e Pesquisador do CNPq. E-mail: pedro.fonseca@ufrgs.br. Agradeço as sugestões de Jorge Ferreira, Pedro Paulo Zahluth Bastos e Sérgio Modesto Monteiro, evidentemente isentando-os pela versão final, e a colaboração dos bolsistas de Iniciação Científica/CNPq André Augustin e Fernando Felber Bataglin.
} 
Ni orthodoxie ni populisme : Le deuxième gouvernement Vargas et l'économie brésilienne

Cet article a pour objets l'économie et les polémiques autour de la politique économique du deuxième gouvernement Vargas (1951-1954) et de son sens historique. Son choix méthodologique est de partir des diverses orientations suivies dans la mise en oeuvre de la politique économique de la période. Celles-ci sont analysées pari passu selon les principaux courants qui partagent leurs analystes et interprètes.

Mots-clés : Vargas - Populisme - National-Developpementisme

\section{Introdução: a Proposta e seus Fundamentos}

Assegura Luis Fernando Veríssimo terem-lhe recomendado nunca iniciar um texto citando Hegel, pois se corre o risco de espantar o leitor logo nas primeiras linhas. ${ }^{1}$ Não obstante o conselho, a referência neste faz-se obrigatória. Sem a pretensão de construir uma análise hegeliana com o rigor necessário que a empreitada exigiria, tributo ao filósofo pelo menos a inspiração do objetivo do artigo, mais modesto, que é contribuir para o estudo da política econômica e da economia do Segundo Governo Vargas (SGV, de ora em diante), tendo como ponto de partida a crítica à literatura sobre o mesmo. Deve-se a Hegel o entendimento de que a crítica do pensamento sobre o real é caminho possível para reconstruir o próprio real. ${ }^{2}$ Ou seja, a análise crítica das percepções, das teorias e do discurso sobre determinado objeto, como movimentos do pensamento, pode tornar-se ponto de partida metodológico para sua apreensão; como devir, seu permanente movimento abre caminho para tanto, embora não assegure nenhum resultado.

Com este respaldo, nota-se, prima facie, que boa parte das polêmicas e embates sobre o SGV remontam a sua época; em certo sentido, a literatura não foge das controvérsias que dividiram os próprios coevos. Em linhas gerais, podem ser delineadas quatro correntes. A primeira defende que o governo era populista, rótulo que vai desde a consideração de que era demagogo e

\footnotetext{
${ }^{1}$ Luis Fernando Veríssimo, "A coruja de Hegel”, Zero Hora, Porto Alegre, 28/05/2009, p.3.

${ }^{2}$ Os marxistas mais afoitos também não precisam desistir da leitura por considerarem tal proposição impregnada de idealismo, o qual se faria necessário "virar de cabeça para baixo", como propôs Marx certa vez. Justamente este foi o procedimento utilizado por ele em Teorias da Mais Valia, com a construção da gênese lógica deste conceito através da crítica à literatura sobre o mesmo, ou seja, percorrendo a história do pensamento econômico.
} 
irresponsável até abranger a denúncia de seu nacionalismo como xenofobia de matiz esquerdista. A segunda corrente, expressa por Skidmore, entende que o governo se divide em duas fases: inicia ortodoxo e posteriormente dá uma "virada nacionalista", mudando radicalmente, pelo que nele se pode notar uma ambivalência. ${ }^{3}$ Já uma terceira propõe que o governo era conservador e ortodoxo, seja com base na política econômica, como Lessa e Fiori e, também, Vianna, seja com base em sua composição e diretrizes no campo político, como D'Araújo. ${ }^{4}$ Uma quarta corrente, à qual nos perfilhamos, defende que se pode detectar no período a existência de um projeto de longo prazo cujo epicentro era a industrialização acelerada e a modernização do setor primário - em linhas gerais o que se convencionou denominar de NacionalDesenvolvimentismo. ${ }^{5}$

Como passo metodológico para dialogar com esses autores, lançar-se-á mão, como recurso analítico, da interpretação proposta em trabalho anterior realizado em coautoria com Sérgio Monteiro, sobre a política econômica do

3 Thomas Skidmore, Brasil: de Getúlio a Castelo, 5.ed, Rio de Janeiro, Paz e Terra, 1976, p. 124.

${ }^{4}$ Carlos Lessa e José Luiz Fiori, "Houve uma Política Nacional-Populista?”, XII Encontro nacional de Economia, São Paulo, ANPEC, 1984; Sérgio Besserman Vianna, A Política Econômica no Segundo Governo Vargas, Rio de Janeiro, BNDES, 1987; Maria Celina Soares D’Araújo, O Segundo Governo Vargas, 1951-1954, Rio de Janeiro, Zahar, 1982.

${ }^{5}$ Sabe-se que quaisquer termos ou expressões para designar fenômenos sociais complexos apresentam limitações, embora não se possa dispensá-los. No caso, prefere-se aqui manter a denominação tradicional de Nacional-Desenvolvimentismo, a qual ainda parece mais apropriada diante das outras opções, como "varguismo" (sugere um projeto mais pessoal), "nacional-populismo" (já traz consigo de imediato uma carga desqualificadora e depreciativa) ou "nacional-estatismo" (posto que, embora a presença do Estado seja fundamental em sua implementação, o projeto contraria o que comumente denota a palavra "estatismo", a qual é usada contrapor estado à sociedade ou, alternativamente, a capitalismo e a mercado. No caso, não representou nem uma imposição do estado à sociedade, posto que nesta foi gestado e enraizado socialmente ao longo de sua vigência, nem tampouco pretendia ocupar o espaço da iniciativa privada ou suprimi-la, já que se tratava de um projeto de desenvolvimento capitalista). Por outro lado, a palavra nacional auxilia em sua diferenciação de outro estilo de desenvolvimento, mais internacionalizante e menos disposto a políticas redistributivas, gestado no governo JK e que aparece de forma mais nítida após 1964. A partir daí, e até o final da década de 1970, continuam o desenvolvimentismo e o PSI (Processo de Substituição de Importações), mas da forma "dependente-associada", como prefere a tradição da Escola de Sociologia da USP (Florestan Fernandes, Fernando Henrique Cardoso, Octavio Ianni), ou que se poderia chamar de "desenvolvimentismo internacionalista", como sugere Marcelo Arend, 50 Anos de Industrialização do Brasil (1955-2005): uma Análise Evolucionária, Tese de Doutorado em Economia, Porto Alegre, UFRGS, 2009. A despeito da denominação, como será argumentado adiante, a execução do projeto não implica impedimento nem incompatibilidade ao fato de, diante da gravidade dos problemas conjunturais, terem sido propostas ou implementadas políticas de estabilização contracionistas no SGV. 
SGV. ${ }^{6}$ Conquanto mais adiante seja apresentada com minudência, tanto em seus fundamentos como na periodização proposta, essa sugere - sem nenhuma pretensão de demarcar fases rígidas, ambiguidade ou "viradas" abruptas de reorientação da política econômica instrumental - que no início do governo houve certo predomínio da busca da estabilidade; seguiu-se-lhe um período de "randomização", o qual se caracteriza por políticas alternadas e simultâneas de contração e expansão da demanda; finalmente, nos últimos meses de governo, detecta-se a preponderância desta última, com abandono do combate à inflação como prioridade. O recurso analítico referido serve também como passo para a divisão das seções do trabalho, posto que os "fatos" do SGV irão sendo expostos pari passu ao seu desfecho, num ir-e-vir entre eles e a literatura. Assim: (1) inicialmente, juntamente com os primeiros meses do governo, serão abordadas as interpretações que consagraram o SGV como populista; (2) a tese da "virada" será questionada a seguir, ao se enfocar o período da "randomização", em que políticas de expansão e contracionistas alternam-se, como se explicará adiante; e, finalmente, (3) os últimos meses do governo conduzem mais apropriadamente para a reflexão sobre as teses defensoras da ortodoxia e do conservadorismo do SGV, as quais serão abordadas juntamente com a do Nacional-Desenvolvimentismo, já que ambas dialogam entre si e, não raramente, apresentam-se como polares.

Cabe aqui assinalar que o trabalho em co-autoria com Monteiro antes referido centra-se tão-somente na política de estabilização, sem a pretensão de ensaiar a coerência ou inconsistência do governo com um projeto mais amplo, seja populista, Nacional-Desenvolvimentista ou conservador. Este registro torna-se imprescindível, porque parte da crítica a ser elaborada aos autores antes mencionados advém de certa confusão sobre a abrangência da expressão "política econômica". Tradicionalmente e de forma genérica esta compreende toda ação do Estado no campo econômico. Em tempos mais recentes, e principalmente pelo mainstream econômico, seu uso restringiuse a políticas de estabilização. Mas estas, a rigor, são apenas parte da política econômica, pois compreendem basicamente as políticas monetárias, cambiais e

\footnotetext{
${ }^{6}$ Pedro Cezar Dutra Fonseca e Sérgio Marley Modesto Monteiro, "Credibilidade e Populismo: a Política Econômica dos Governos Vargas e Goulart". In: Revista Brasileira de Economia, Rio de Janeiro, n. 2, v. 59, abr./jun. 2005, p. 215-243. Ou: Anais do XXX Encontro Nacional de Economia da ANPEC/SEP. Nova Friburgo, 2002 [CD, www.anpec,org.br]. A metodologia e a concepção analítica encontram-se mais bem detalhadas em: Sérgio Monteiro, Política Econômica e Credibilidade: uma Análise dos Governos Jânio Quadros e João Goulart, Tese de Doutorado em Economia, Porto Alegre, UFRGS, 1999.
} 
fiscais (em alguns casos também a salarial, quando adotada com o propósito de estabilizador), as quais serão aqui denominadas de políticas instrumentais, pois se voltam basicamente ao enfrentamento dos dilemas da conjuntura, contexto em que não se pode ignorar a estabilidade como variável relevante, e possuem uma lógica própria segundo determinados cânones assentados pela "sabedoria econômica convencional”, para usar a expressão de Castro e Souza. ${ }^{7}$ Mas a ação do Estado no campo econômico a elas transcende, pois este também propõe e executa medidas de maior envergadura, estruturais e institucionais, com alcance de longo prazo e capazes de abrir novos caminhos e alternativas: leis, códigos, empresas estatais, órgãos, conselhos, tratados internacionais e projetos de impacto são ações governamentais que transcendem às políticas instrumentais, mas nem por isso podem ser negligenciadas pela "História Econômica". As políticas instrumentais muitas vezes são utilizadas como meio cujo fim é a própria estabilização; podem até colaborar para efetivação de projetos de maior envergadura, mas nem sempre e, não raro, podem até afigurarem-se como contraditórias a eles. Assume-se aqui como pressuposto - por sua obviedade que a relação entre estrutura e conjuntura não é linear nem unívoca, posto que permeada por variáveis extraeconômicas, principalmente de cunho político. A percepção de projetos de longo prazo, por parte do analista preocupado em captar o sentido e intenções da ação governamental, torna-se mais viável ao se incorporar este outro conjunto de variáveis. Em outro trabalho, sobre a gênese do Nacional-Desenvolvimentismo na década de 1930, assumiu-se a mesma metodologia para mostrar que já nesta se detectam evidências quanto à existência de um projeto de industrialização implementado e defendido de forma deliberada e consciente pelo governo. ${ }^{8}$ A literatura econômica, em parte por centrar-se nas políticas instrumentais, normalmente considera que isso só teria ocorrido na década de 1950.

Com essas observações em mente, enunciam-se as seguintes hipóteses de trabalho sobre o SGV:

\footnotetext{
${ }^{7}$ Antonio Barros de Castro e Francisco Pires de Souza, A Economia Brasileira em Marcha Forçada, São Paulo, Paz e Terra, 1985, p. 27. A utilização desta expressão deve-se ao fato de ser mais abrangente que mainstream, pois supõe tanto a ortodoxia como a heterodoxia. Por exemplo: os pensamentos keynesiano, pós-keynesiano e estruturalista podem não fazer parte da "linha principal" de hegemonia neoclássica, mas não são estranhos ao "saber convencional" dos economistas.

${ }^{8}$ Pedro Cezar Dutra Fonseca, "Sobre a Intencionalidade da política Industrializante no Brasil na Década de 1930”. In: Revista de Economia Política, São Paulo, jan./mar. 2003, n. 89, p.133-148.
} 
(1) trata-se de governo afinado com o que se convencionou denominar de Nacional-Desenvolvimentismo, este entendido mais precisamente como um projeto de longo prazo centrado na industrialização e na modernização do setor primário, implementado com auxílio de medidas governamentais voltadas a incentivar a substituição de importações e a diversificação da produção primária, com prioridade ao mercado interno. O projeto, tal como se entende, não excluía o capital estrangeiro nem os setores agrários; estes, inclusive, embora divididos, mais o apoiaram do que lhe fizeram oposição, embora se registrem resistências entre os segmentos ligados à exportação;

(2) não há incompatibilidade em um governo afinado com o Nacional-Desenvolvimentismo, em certas conjunturas e diante de certas circunstâncias, optar por políticas de estabilização austeras ou contracionistas. Esta asserção por certo é mais polêmica e menos afinada com o senso comum, mas vincula-se ao entendimento de que as políticas instrumentais são limitadas tanto para detectar projetos de longo prazo como para denunciar suas possíveis incoerências ou inexistência. Vejamos por quê.

\section{Os Dilemas da Conjuntura e a Tentativa Inicial de Estabilização}

Ao tomar posse como Presidente da República, em janeiro de 1951, Vargas deparou-se com uma conjuntura econômica que emitia sinais de agravamento de um quadro de dificuldades. Os indicadores não eram alarmantes, mas já passara o clima de euforia dos últimos anos da II Guerra e do início do Governo Dutra. Este, possivelmente interpretando que o estrangulamento externo verificado na década de 1930 era coisa do passado, optou por uma política de liberalização no mercado cambial, a qual em poucos meses trouxe de volta o problema crônico deparado pelas autoridades econômicas desde a Grande Depressão: o fechamento das contas do balanço de pagamentos (ver Gráfico 1). Na metade do ano de 1947, a política econômica inverteu o sinal e começou a intervenção no mercado cambial através da Instrução $n^{\circ} 25$ da Superintendência da Moeda e do Crédito - SUMOC, com a determinação da obrigatoriedade de as instituições que operavam com moedas arbitráveis venderem $30 \%$ das divisas ao Banco do Brasil segundo a taxa oficial. ${ }^{9}$ Mas,

${ }^{9}$ Fausto Saretta, Política Econômica Brasileira, Araraquara, Unesp, 2000, p. 89. Ver também: Pedro Paulo Z. Bastos, "O Presidente Desiludido: a Campanha Liberal e o Pêndulo 
mais importante, começou no Governo Dutra uma administração política dos problemas cambiais que vigoraria até o governo Jânio Quadros, no início dos anos 60: em substituição aos mecanismos "normais" de mercado, passaram a se estabelecer, através de diferentes instrumentos, prioridades a determinadas importações, ao privilegiarem-se produtos classificados como "essenciais". Embora tradicionalmente a memória histórica tenha registrado como marca do Governo Dutra o liberalismo daqueles primeiros meses - o qual, associado à declaração de ilegalidade do Partido Comunista Brasileiro (PCB), em 1948, e sua simpatia pessoal pelo nazi-fascismo no início da II Guerra, consagrou sua imagem de conservadorismo -, esta discricionariedade mostra alinhamento com a defesa do Processo de Substituição de Importações (PSI) e opção pela continuidade do projeto de desenvolvimento acelerado, assentado na industrialização, que vinha sendo implementado desde a década de 1930. Por essenciais, entendiam-se via de regra os bens de capital e intermediários, como insumos básicos necessários à produção industrial e à modernização agrícola. Em decorrência, impunham-se barreiras à importação de bens de consumo já produzidos internamente ou cuja oferta doméstica se pretendia estimular, bem como a bens considerados supérfluos.

Em parte, as dificuldades econômicas decorriam do acordo de Bretton Woods (1944), o qual estabelecera a adoção de taxas fixas de câmbio em relação ao dólar, ora definido como moeda por excelência para as transações internacionais. O Brasil acumulara na guerra parte de suas divisas em moedas agora não mais conversíveis - de forma que a leitura do balanço de pagamentos em parte camuflava a extensão da gravidade da escassez de dólares. A adoção da taxa fixa de Cr $\$ 18,50$ por dólar, em cotação próxima ao período anterior à guerra, significava uma valorização real do cruzeiro, a qual gradualmente se tornava mais problemática com o crescimento da inflação. Até quando se poderia manter a taxa fixa era o grande dilema, pois o dólar barato desestimulava o setor exportador e as importações tendiam a crescer. As interpretações sobre o período assinalam, acertadamente, que se tratava, do ponto de vista distributivo, da utilização do mecanismo cambial para proporcionar transferência de renda do setor exportador para a indústria e para quem dependia de insumos importados (como adubos para a agricultura, por exemplo). A oposição, liderada pela União Democrática Nacional (UDN), levantava uma bandeira liberal ao denunciar o intervencionismo e o PSI: rejeitava ferrenhamente essa opção do de Política Econômica no Governo Dutra (1942-1948)", in: História Econômica e História das Empresas, volume VII.1, junho 2004. 
governo, assumindo a defesa do setor exportador e do "consumidor nacional", o qual pagava mais caro por bens que poderia importar, sem contar a melhor qualidade dos similares estrangeiros. A despeito disso, em fevereiro de 1948 o Governo Dutra tomou sua medida mais arrojada: o denominado "contingenciamento de importações": mantinha a taxa cambial fixa e administrava a escassez de dólares condicionando as operações de importação à obtenção de "licenças prévias", as quais eram concedidas pelo critério de essencialidade.

Vargas assume nesse quadro, com a valorização real do cruzeiro e de escassez de moedas conversíveis, além de crescimento da inflação, a qual, medida pelo Índice de Preços ao Consumidor do Rio de Janeiro, praticamente triplicara em dois anos: de 3,4\% em 1948 para 9,4\% em 1950 (ver Gráfico 2). Esta aceleração dos preços não era desprezível, a contar que, além das políticas de austeridade já adotadas, mais duas medidas do Governo Dutra serviam como âncora anti-inflacionária: a fixação da taxa cambial do cruzeiro com o dólar e o congelamento do salário mínimo durante todo o seu mandato, mantendo-o no mesmo nível de 1943 (ver Gráfico 3). Soma-se a essas, ao final do seu mandato, certo afrouxamento na concessão de licenças - talvez com o propósito de ajudar no controle da inflação -, mas com o agravante de repercutir negativamente no balanço de pagamentos, ainda mais abalado na conjuntura com a retração do comércio mundial devido à Guerra da Coréia e a uma crise internacional na indústria têxtil de algodão, segundo item da pauta de exportações, depois do café.

Durante a campanha eleitoral, como candidato, Vargas defendera exaustivamente a necessidade de crescimento acelerado. ${ }^{10}$ Este adviria tanto de investimentos privados, voltados à modernização do setor primário e ao aprofundamento da industrialização - a qual deveria avançar dos bens de consumo para os bens de capital -, quanto de investimentos públicos em infraestrutura, como transportes, comunicações e energia. Mesmo nos estados menos industrializados (cujos eleitores e dirigentes, em princípio, seriam menos sensíveis às "causas da indústria") defendeu este projeto, em síntese o que mais tarde os analistas denominariam de Nacional-Desenvolvimentismo. As dificuldades da conjuntura, entretanto, limitavam sua execução e impunham cautela. A rigor, deparava-se com o clássico dilema entre estabilização versus crescimento: crescer envolvia mais importações de insumos e de bens de ca-

${ }^{10}$ Pedro Cezar Dutra Fonseca, Vargas: o Capitalismo em Construção, São Paulo, Brasiliense, 1989, p. 347. 
pital, além de mais gastos públicos e consumo doméstico, os quais aguçariam os problemas do balanço de pagamentos e da inflação. Que caminho seguir não dependia apenas de vontade política: caso a opção fosse pelo crescimento, teria provavelmente voo curto: a inflação corroía as finanças estatais, os investimentos privados e os salários - variáveis indispensáveis para um crescimento sustentado -, ao mesmo tempo em que a substituição de importações para novos segmentos exigia a curto prazo importação de outros bens, o que tornava cada vez mais difícil a substituição e repunha, contraditoriamente, o estrangulamento externo. ${ }^{11}$

A saída encontrada foi diminuir o ritmo do crescimento a curto prazo, a permitir a leitura segundo a qual, na percepção da equipe econômica, liderada pelo Ministro da Fazenda Horácio Lafer, tratava-se de problema conjuntural. Contava em favor de certo otimismo a recuperação, desde meados de 1949, dos preços internacionais do café, e havia sinais positivos por parte do presidente norte-americano Truman com relação ao Brasil - lembrem-se o papel destacado de Osvaldo Aranha na ONU, o contexto de Guerra Fria e a emergência da Guerra da Coréia, para a qual se esperava o envio de tropas brasileiras e o mesmo alinhamento seguido com os EUA na II Guerra. Em julho de 1951 foi instalada a Comissão Mista Brasil-Estados Unidos, a qual deveria elaborar um diagnóstico da economia brasileira e propor um conjunto de projetos de desenvolvimento, a ser financiado pelo BIRD e pelo EXIMBANK, com a expectativa do governo brasileiro de receber até US $\$ 300$ milhões. A solução ao dilema - não apenas no plano retórico, mas materializado em medidas -, veio com a adoção por Lafer da "fórmula" Campos Salles-Rodrigues Alves, pela qual primeiro dever-se-ia passar por uma etapa de saneamento, com prioridade ao equilíbrio orçamentário e ao combate à inflação, mesmo em prejuízo ao crescimento econômico (o que lembrava a política ortodoxa de Campos Salles), para, após conseguida a estabilidade, ingressar-se numa fase de crescimento (Rodrigues Alves). Sua defesa buscava um delicado equilíbrio entre o ideário pró-estabilização e as promessas desenvolvimentistas da campanha presidencial, não abandonadas por Vargas após a posse, e que também contava com apoio de parte significativa da equipe, como de Ricardo Jafet, Presidente do Banco do Brasil, e da Assessoria Econômica de Vargas. Esta subordinava-se diretamente à Presidência da República e voltava-se a pensar

${ }^{11}$ Maria da Conceição Tavares, Da Substituição de Importações ao Capitalismo Financeiro, Rio de Janeiro, Zahar, 1972, p. 40-43. 
e propor medidas de largo prazo; em sua composição contava com homens de tradição desenvolvimentista, como Rômulo de Almeida (chefe), Ignacio Rangel, Jesus Soares Pereira, João Neiva de Figueiredo, Cleanto de Paiva Leite e Tomás Pompeu Acioli Borges. Como assinala Vianna, a "fórmula" também viria possibilitar a "articulação das forças políticas e interesses divergentes em torno da ação do governo". ${ }^{12}$ Mas desta última afirmação não se pode inferir qualquer ortodoxia ou liberalismo como ideologia dominante: apesar desta controvérsia sobre a condução da política econômica, como é normal em conjuntura problemática como essa, é preciso assinalar que o ideário desenvolvimentista predominava no governo como um todo e principalmente em Vargas, cujo discurso, desde a década de 1930, "mostra a tentativa de conciliar o crescimento com o equilíbrio das finanças". ${ }^{13}$

Assim, por estranho que possa parecer para quem ingenuamente quer ver na política um exercício de lógica aristotélica, no primeiro ano de governo registra-se claramente a coexistência de um discurso desenvolvimentista com outro cujo epicentro era a estabilização. A Mensagem Presidencial enviada ao Congresso Nacional na abertura do ano legislativo de 1951 a ilustra com menções, em várias passagens, ao projeto maior de desenvolvimento econômico com justiça social; todavia acrescenta que, de fato, por ora se tinha "pouco a dividir" e dever-se-ia impedir que "uma distribuição insensata venha prejudicar o potencial de capitalização necessário ao desenvolvimento econômico geral e, assim, à criação de maiores e mais amplas oportunidades de emprego e salários". ${ }^{14}$ Surpreende esta manifestação com reconhecimento a uma relação inversa entre taxa de crescimento dos salários e nível de emprego, já que tese oposta - defensora do salário como demanda, a qual propunha não apenas a compatibilidade, mas o impacto positivo de seu crescimento nos níveis de produção e emprego - era dominante no ideário trabalhista e utilizada pelo

${ }^{12}$ Vianna, op.cit., 1987, p.37.

${ }^{13}$ Pedro C. D. Fonseca, op. cit. p. 382. Esta interpretação contraria a de Vianna (op. cit. p. 120), para quem Vargas teria uma "visão ortodoxa em assuntos de economia. Desde a época em que geriu o Ministério da Fazenda de Washington Luís até sua morte, as convicções do pensamento econômico ortodoxo foram as suas". Na verdade, estas "convicções" só se fizeram presentes no pensamento de Vargas na Primeira República, quando adepto do positivismo, mas começaram a ser abandonadas já em 1928, ao assumir a Presidência do Rio Grande do Sul (Ver: Pedro Cezar Dutra Fonseca, "Gênese e Precursores do Desenvolvimentismo no Brasil”, Pesquisa छ̈ Debate, São Paulo, PUCSP, v. 15, n. 2(26), jul./dez. 2004, p.225-56).

${ }^{14}$ Getulio Vargas, O Governo Trabalhista do Brasil, Rio de Janeiro, José Olympio, 1952, vol. 1, p.73. 
próprio Vargas, desde o Estado Novo, como um dos argumentos em defesa da legislação social. Consta da mesma Mensagem crítica áspera ao governo anterior, responsabilizando-o pela emissão de moeda irresponsável e pelo déficit público, cuja solução, então enfaticamente defendida, passava por "medidas rigorosas de compressão de despesas" e aumento de arrecadação. Vários outros pronunciamentos presidenciais de 1951 seguem a mesma linha. ${ }^{15} \mathrm{E}$ esta postura não se restringiu ao plano das idéias e do convencimento retórico, pois se materializou em políticas que resultaram na queda de $3 \%$ do investimento público em 1951, com relação ao ano anterior, e na retração expressiva da participação governamental na formação bruta de capital fixo, de 28,4\% para 20,3\% do PIB no mesmo período. A meta de superávit orçamentário foi viabilizada com crescimento real da receita da União entre 1950 e 1951, de Cr\$19,37 para Cr\$ 23,17 bilhões, enquanto as despesas caíam de Cr\$23,67 para Cr\$20,78 bilhões, em valores de $1950 .{ }^{16}$ Como consequência, houve desaceleração no ritmo de crescimento do PIB em 1951 com relação a 1950, com taxa de 4,9\%, a qual contrasta com os $9,7 \%$ e 7,7\% do biênio 1948-49 e, principalmente, com a queda do crescimento do produto industrial para 5,3\%, quando atingira 11$12 \%$ nos últimos anos do Governo Dutra (ver Gráfico 2). ${ }^{17}$

Essa tentativa de estabilização durou até meados de 1952. Como um dos primeiros sinais de seu afrouxamento registra-se a expansão do crédito por parte do Banco do Brasil, cujo presidente, Ricardo Jafet, tradicionalmente apresentava perfil francamente desenvolvimentista. Fora sugerido para o cargo por Ademar de Barros, governador de São Paulo, líder do Partido Social Progressista (PSP) e quem também indicara Café Filho para Vice-Presidente da República, selando a aliança deste partido com o Partido Trabalhista Brasileiro (P'TB), pelo qual Vargas se candidatara.

Pode-se afirmar, cum grano salis, que a consequência mais impactante dessa política econômica não se deu nas variáveis econômicas da conjuntura - apesar da exitosa interrupção da trajetória ascendente da inflação, a qual se logrou estabilizar em torno de $12 \%$-, mas na historiografia sobre o período. A dificuldade quanto ao entendimento de que um governo considerado

\footnotetext{
${ }^{15}$ Id. p. 140. Veja, ainda: Getulio Vargas, A Política Trabalhista no Brasil, Rio de Janeiro, José Olympio, 1950.

${ }^{16}$ IBGE, Estatísticas Históricas do Brasil, Rio de Janeiro, p. 571. Os dados foram deflacionados pelo deflator implícito do PIB.

${ }^{17}$ Marcelo de Paiva Abreu (org.), A Ordem do Progresso; Cem Anos de Política Econômica Republicana - 1889-1989, Rio de Janeiro, Campus, 1989, p. 398-403.
} 
Nacional-Desenvolvimentista, em determinada conjuntura e dentro de certas circunstâncias, possa ou seja forçado a executar políticas de estabilização de cunho contracionista, levou às interpretações mais surpreendentes e desencontradas, marcadas por visões radicalmente opostas. Vejamo-las a seguir, começando pela que denomino "imaginação do populismo".

\section{O Populismo Entra em Cena}

As teses sobre o populismo na América Latina no século XX encontraram no Brasil campo fértil na intelectualidade, principalmente de matiz marxista, nas décadas de 1960 e 1970. Tratava-se, sobretudo, de uma interpretação sobre o interregno de 1946 a 1964 como uma continuidade do autoritarismo enraizado historicamente no país: negligenciavam-se a experiência democrática e os movimentos sociais do período sob o entendimento de que havia uma manipulação das "massas", principalmente urbanas, por parte de líderes geralmente carismáticos que atendiam parcialmente suas demandas e contabilizavam seus resultados em benefício próprio, dificultando a ação dos sindicatos e dos partidos da "verdadeira" esquerda, concebida como porta-voz dos "reais" interesses da classe operária e vanguarda responsável por liderar a revolução social em direção ao socialismo. É interessante notar que ora se considerava o proletariado sujeito da história e classe responsável pelo papel histórico da transformação, ora fraco, sem consciência política e manipulável por líderes populistas, o que legitimava a necessidade de uma vanguarda esclarecida. Esta versão crítica a governos como de Vargas e Goulart, no caso brasileiro, logo extrapolou os livros e debates acadêmicos e encontrou campo ainda mais fértil na mídia e na política oficial: políticos conservadores, principalmente após 1964, passaram a adotar a qualificação de "populismo" para designar tudo aquilo a que se opunham e cujo golpe militar viera debelar: o nacionalismo, a legislação trabalhista, as reformas de base, os sindicatos e as mobilizações urbanas e rurais. ${ }^{18}$

\footnotetext{
${ }^{18}$ As reflexões teóricas mais instigantes sobre populismo devem-se a Gino Germani, Torcuato di Tella e Ernesto Laclau. Sobre a origem da utilização do termo populismo no Brasil, veja os artigos de Ângela de Castro Gomes e Jorge Ferreira em: Jorge Ferreira (org.), O Populismo e sua História; Debate e Crítica, Rio de Janeiro, Civilização Brasileira, 2001. Nestes e nos demais artigos da obra encontra-se revisão de literatura sobre os principais autores que colaboraram para construir o conceito de populismo. Também há uma síntese dos autores brasileiros em: Mercedes M. L. Cánepa, “Classes Sociais e Populismo”, Textos para Discussão, Porto Alegre, Núcleo de Pesquisas e Estudos sobre a Política Rio-Grandense, IFCH/ UFRGS, 1990.
} 
É fenômeno intrigante como essa adjetivação comoveu personagens de matizes ideológicos diferentes e antagônicos, cada um dela fazendo o uso que lhe aprazia. O sentido do "uso" variava entre um caso e outro, mas não o imaginário sobre a "manipulação": a ignorância e a parca consciência política das massas caíam como uma luva para explicar tanto sua predisposição para apoiar políticos burgueses como para justificar o golpe militar. Os dois extremos do campo político, portanto, lançaram mão do "imaginário do populismo" como forma de sintetizar as dificuldades e, no limite, a inviabilidade da democracia em países como o Brasil. Parece indiscutível que das referidas ignorância e baixa consciência decorriam a inutilidade do jogo eleitoral, dos partidos políticos e das liberdades civis e políticas; na práxis cotidiana, consistiam em preâmbulo para justificar uma intervenção "pelo alto" salvadora, seja de uma vanguarda revolucionária, em um caso, seja dos militares, em outro. Desvela-se aí a contradição inarredável do discurso: o autoritarismo populista só poderia ser salvo por outro autoritarismo, de forma que o fundamento da crítica só se realizaria historicamente se o discurso assumisse sua própria contradição. O "imaginário do populismo", em ambos os casos, revela seu elitismo ao assumir-se como a razão esclarecida - à qual, no debate acadêmico, acrescenta-se ainda a gravidade de desqualificar o objeto da pesquisa, primeiro passo para negligenciar sua complexidade e induzir a resultados que, a rigor, são os próprios pré-supostos e pré-conceitos do investigador.

As considerações acima procuraram sumariar o núcleo das construções teóricas que frisam o populismo como fenômeno político, posto que seus adeptos buscam alicerçar suas análises principalmente em termos teóricos e variáveis tradicionalmente consagrados no âmbito da Ciência Política. Há, todavia, autores que procuram descrever o fenômeno do populismo na formulação da política econômica; este último tem como objeto de pesquisa o que seus proponentes denominam de populismo econômico. Ambas as construções teóricas por certo se inter-relacionam ao compartilharem de concepções comuns mais gerais e abstratas sobre o que seria o populismo (manipulação, demagogia e nacionalismo, por exemplo, fazem parte de ambas), mas academicamente constituem agendas de pesquisa diferentes, além de poderem existir separadamente. ${ }^{19}$

\footnotetext{
${ }^{19}$ Bresser Pereira, por exemplo, menciona Perón e Allan Garcia como casos em que ambos coincidem. Salvador Allende seria um líder socialista e não populista, do ponto de vista político, mas sua política econômica constitui exemplo de populismo econômico. Vargas seria o contrário. Ver: Luiz Carlos Bresser Pereira (org.), Populismo Econômico: Ortodoxia, Desenvolvimentismo e Populismo na América Latina, São Paulo, Nobel, 1991, p.8.
} 
O populismo político latino-americano como objeto de análise é o mais antigo, conhecido e estudado. No caso brasileiro, seu foco irradiador e construtor das análises mais robustas foram autores como Francisco Weffort, Fernando Henrique Cardoso e Octavio Ianni. Não cabe aqui repisar seus argumentos, sobejamente discutidos na literatura. Cardoso e Faletto ilustram perfeitamente esta abordagem, facilmente associada ao Brasil e a outros países latino-americanos da época do SGV, ao vincular o fenômeno do populismo à transição entre uma sociedade tradicional/agrária a outra, urbano/industrial, como o elo através do qual se vinculam as massas urbanas mobilizadas pela industrialização - ou expulsas do setor agrário como consequência de suas transformações ou de sua deterioração - ao novo esquema de poder; e converter-se-á na política de massas, que tratará de impulsionar a manutenção de um esquema de participação política relativamente limitado e baseado em uma débil estrutura sindical que não afetou as massas rurais nem o conjunto do setor popular urbano. ${ }^{20}$

Nota-se nesta passagem o entendimento de que a emergência do populismo político decorria de uma causa econômica: a industrialização e a urbanização. Os termos falam por si: "massas" (em oposição a classes sociais ou a cidadãos), "expulsas", "deterioração", "limitado", "débil”... Registra-se, todavia, que mesmo nesses autores pode-se encontrar uma segunda definição, mais sofisticada, na qual populismo transcendia a simples manipulação. Embora sempre em coexistência com a "falta de consciência" da classe operária, defenderam que esta manipulação não era absoluta nem sem contradições, o que abria espaço para manifestações próprias dos trabalhadores e dos "estratos médios" da população urbana. Weffort, por exemplo, assevera que o populismo "foi um modo determinado e concreto de manipulação das classes populares, mas foi também um modo de expressão de suas insatisfações", pelo que o domínio das classes dominantes se tornava "potencialmente ameaçado". ${ }^{21}$

Merece menção, ainda, que tais considerações não são especificamente focalizadas no SGV, cujo período não foi objeto de estudo sistemático por

${ }^{20}$ Fernando Henrique Cardoso e Enzo Faletto, Dependência e Desenvolvimento na América Latina, 4.ed., Rio de Janeiro, Zahar, 1977, p. 103.

${ }^{21}$ Francisco Weffort, "O Populismo na Política Brasileira”, in: Celso Furtado, Brasil: Tempos Modernos, 2.ed., Rio de Janeiro, Paz e Terra, 1977, p. 51. Uma outra forma de mostrar que não se tratou de mera manipulação ou passividade da classe trabalhadora consta de trabalho mais recente, com a utilização da teoria dos jogos, de: Carla Fernanda da Silva, Populismo no Brasil na Década de 1930: uma Aplicação à Teoria dos Jogos, Dissertação de Mestrado em Economia, Porto Alegre, UFRGS, 2008. 
eles, com exceção do capítulo dedicado ao mesmo em Estado e Planejamento Econômico no Brasil de Ianni. ${ }^{22}$ Nos demais autores, trata-se de reflexões e considerações abrangentes sobre o período de 1946-64 (embora, às vezes, o período populista apareça como começando em 1930, com o "estado de compromisso" decorrente da crise da hegemonia cafeeira agroexportadora). De qualquer forma, Vargas e Goulart são os personagens de referência ao tratarem do populismo brasileiro em seus trabalhos, conquanto registrem a diferenciação entre o que seria o populismo destes, de caráter reformista, e outro, "de direita", moralizador e não nacionalista, como de Ademar de Barros e Jânio Quadros. Ademais, cabe também reter que estes autores, embora críticos do populismo identificado nestes governos, não negaram a existência do Nacional-Desenvolvimentismo como ideologia ou projeto: procuravam mostrar suas contradições - como a fraqueza da "burguesia nacional" (esta entendida como a burguesia industrial) para o implementar, as dificuldades de um capitalismo "autônomo" em países periféricos e a tendência menos ao antagonismo e mais à associação com o capital estrangeiro por parte das elites, tanto na esfera produtiva como no consumo imitativo. Ao assim procederem, reconheciam o Nacional-Desenvolvimentismo como fenômeno histórico, ou seja, aceitavam intelectualmente a existência de um projeto, encampado por parte das elites ou classes dirigentes do país, centrado na proposta de industrialização e com o propósito maior revelado de desenvolvimento econômico, o qual traria consigo a utopia recorrente a valores como soberania nacional, justiça social e maior equidade.

Quanto ao populismo em matéria econômica, embora a terminologia, em sentido lato, remonte à segunda metade do século XIX para designar defensores de teses reformistas tanto na Rússia como nos Estados Unidos, foi a partir da década de 1980 que ganhou expressão na literatura econômica, e desde logo novamente a América Latina se mostrou como o palco por excelência para a aplicação do conceito e sua difusão. $\mathrm{O}$ fim das ditaduras militares em vários países propiciou a ascensão de governos comprometidos com o atendimento de "demandas represadas", trazendo de volta a inflação galopante, o aumento do déficit público e a resistência às teses liberais, como do Consenso de Washington. A falta de enraizamento democrático e de instituições liberais sólidas teria criado, juntamente com outros fatores, condições permissivas

22 Octavio Ianni, Estado e Planejamento Econômico no Brasil (1930-1970), Rio de Janeiro, Civilização Brasileira, 1977, p. 107-138. 
para a chegada ao poder de governos civis "fracos", de escassa legitimidade, incapazes de levar adiante o conjunto de reformas recomendado para a construção de uma rota de crescimento de longo prazo. Numa adaptação à política econômica que lembra o antigo modelo de Rostow, entende-se que o sacrifício do presente seria pré-condição para o crescimento futuro. Assim, ao lado de políticas de estabilização de caráter ortodoxo, com prioridade ao combate à inflação, dever-se-iam implantar reformas estruturais impopulares, como a desregulamentação do mercado de trabalho, abertura ao comércio exterior, restrição à previdência social pública e focalização das políticas sociais, sem as quais o crescimento de longo prazo resultaria inviabilizado.

A barreira a esse projeto não teria partido da esquerda tradicional, enfraquecida pela crise da União Soviética e do "socialismo real”, mas por governos conservadores (como José Sarney no Brasil e Raúl Alfonsín na Argentina) que procuravam legitimar-se com "apelo direto às massas". Retornava ao subcontinente o fantasma do populismo: nacionalismo econômico, demagogia com o gasto público, prebendalismo e incapacidade de implementação de políticas restritivas de combate à inflação, com a adoção por parte dos governos de políticas cambiais e monetárias contrárias à estabilidade. ${ }^{23} \mathrm{O}$ exemplo mais típico para o caso brasileiro seria o Plano Cruzado: enquanto a literatura de Ciência Política viu ressuscitar o populismo com os "fiscais do Sarney" e a manipulação das "massas" com o congelamento, em economia tratava-se de denunciar que as medidas do plano não só eram inócuas (com a recusa da teoria inercialista de aceitar o déficit público primário como causa da inflação e ao sugerir como alternativa o expediente do congelamento, heterodoxia contrária ao sistema de livre formação de preços), mas também inconsistentes: como explicar a opção pelo congelamento do câmbio, com previsível consequência sobre o equilíbrio externo? E a elevação do salário mínimo e dos demais salários, a gerar uma pressão de custo no próprio dia do congelamento? E, finalmente, o "gatilho" salarial em pleno plano cujo fundamento teórico era o inercialismo, de onde decorria a exigência de acabar com a indexação?

O sentido e o significado do que seja "populismo econômico" deve ser buscado no mainstream teórico, pois este é quem o trouxe à baila como objeto

${ }_{23}$ Terminologia de inspiração weberiana, prebendalismo refere-se a uma relação de dominação na qual o governante concede prebendas, materiais ou simbólicas, em dinheiro ou não, em troca de apoio e em busca de maior legitimidade, geralmente através de um quadro administrativo. O líder populista, no caso, usaria o Estado - leis, cargos, arrecadação - para distribuir prebendas com vistas a fortalecer seu poder político. 
de pesquisa e o consagrou como interpretação sobre a forma de condução da política econômica. A definição mais precisa e difundida de populismo econômico nessa nova concepção deve-se a Dornbusch e Edwards. Para estes, " $a$ policy perspective on economic management that emphasizes economic growth and income redistribution and deemphasizes the risks of inflation and deficit finance, external constraints and the reaction of economic agents to aggressive nonmarket policies" ${ }^{24}$ Bresser Pereira, na mesma direção, assevera: "O populismo econômico está baseado em um distributivismo ingênuo e em um desenvolvimentismo que não mede custos. Desenvolvimento econômico e distribuição de renda são entendidos como dois objetivos que podem ser alcançados com relativa facilidade pelo, de um lado, aumento dos investimentos e dos gastos sociais do Estado, e, de outro, pelo aumento de salários". ${ }^{25}$

De acordo com Dornbusch e Edwards, o paradigma populista na economia caracteriza-se por quatro fases. A primeira fase seria de altas taxas de crescimento do produto, dos salários reais e do emprego. A expansão da demanda é compensada pela redução de estoques e aumento das importações, aliviando-se o impacto sobre os preços. O financiamento das importações pode se dar por redução das reservas ou suspensão dos pagamentos ao exterior. $\mathrm{Na}$ segunda fase começam a aparecer os gargalos na produção. Os estoques estão reduzidos e são necessários realinhamentos de preços, desvalorizações e controles cambiais ou protecionismo. Paralelamente, a inflação aumenta, embora os salários permaneçam elevados, e o déficit público piora. Na terceira fase, a oferta insuficiente de bens e serviços, a aceleração da inflação e os problemas cambiais levam à fuga de capitais e à desmonetização da economia. O déficit público piora ainda mais e os salários reais caem. As políticas instrumentais tornam-se instáveis. Na última fase, sob um novo governo, políticas de estabilização de cunho ortodoxo são implementadas. Em síntese, a mensagem de Dornbusch e Edwards é clara e é a mais aceita no mainstream econômico: a política econômica populista consiste na opção pelo crescimento a curto prazo sem reconhecer as restrições econômicas, o que faz gerar inúmeros problemas a médio prazo e, com isso, joga para o futuro seu custo após uma fase de brilho

\footnotetext{
${ }^{24}$ Rudiger Dornbusch e Sebastian Edwards, The Macroeconomics of Populism in Latin America, Chicago, The University of Chicago Press, 1991, p. 9. [“uma perspectiva de política a respeito do gerenciamento econômico que enfatiza crescimento econômico e redistribuição de renda e relega a segundo plano os riscos de inflação e o déficit público, restrições externas e a reação dos agentes econômicos a políticas agressivas contrárias ao mercado"].

${ }^{25}$ Bresser Pereira, op. cit. p. 8.
} 
fugaz e artificial. Seu desfecho é o retorno à política ortodoxa: a sociedade acaba pagando mais tarde pela demagogia e insensatez do governante populista.

Importante pressuposto do modelo é a curva de Philips, de onde se extrai o dilema deparado pelos governantes no curto prazo: crescimento ou estabilização? O populismo econômico revela-se incapaz de optar pela última: "Policymakers explicitly reject the conservative paradigm". ${ }^{26}$ Vale aqui a mesma observação anteriormente feita com relação ao populismo político e suas críticas ao SGV: a adjetivação de populista ajusta-se, sem qualquer pudor, ao que o próprio analista pretende criticar, ou seja, o modelo começa com a pretensão de "ciência positiva", mas a pretensão de formalizar uma rota ideal ou desejável para confrontar com o comportamento dos policymakers acaba facilmente transformando-o em instrumento para julgar sua atuação. Os pressupostos e as hipóteses explicitam-se como juízos de valor: populismo não é um fenômeno que se quer entender ou explicar, mas denunciar. Como bem afirma Jorge Ferreira tendo em vista o jogo da política: populismo é sempre "o Outro". ${ }^{27}$ A ortodoxia neoclássica, sem fugir à regra, comunga do mesmo princípio da velha ortodoxia comunista que nos anos 50 do século passado inconsolavase ao ver as "massas" não seguirem o previsto nos manuais de materialismo histórico e se deixarem manipular por políticos burgueses: é comum às ortodoxias de diversos matizes a desqualificação do que lhe é estranho, contrário ao pensamento arraigado ou "correto". Como certa vez asseverou Gramsci, o pensamento ortodoxo repousa na convicção de "bastar-se a si mesmo", fenômeno claramente detectado nesses críticos do SGV. ${ }^{28}$

${ }^{26}$ Dornbusch e Edwards , op. cit. p. 9. ["Policymakers rejeitam explicitamente o paradigma conservador"].

${ }^{27}$ Jorge Ferreira (org.), op.cit. p. 124.

${ }^{28}$ Antonio Gramsci, Concep̧̧ão Dialética da História, Rio de Janeiro, Civilização Brasileira, 1986, p.186. Ver: Fonseca, op.cit., 1989, p. 389. Neste trabalho, ao tratar do tema, escrevi: “'Bastar-se a si mesmo' significa praticamente a exigência para um conjunto de idéias ou de teorias rejeitar quaisquer outras que lhe são estranhas, inibindo as inovações e afirmandose como pensamento dominante. A ortodoxia, em geral, vira 'receituário', ou seja, dita e aconselha ações (políticas, econômicas) desde que se cumpram os pré-requisitos estabelecidos por ela mesma, sem levar em consideração outros aspectos e peculiaridades (os quais passam, então, a ser explorados por seus críticos) (Fonseca, 1989, p. 380, grifos originais). Embora nesse trabalho, escrito em meados da década de 1980, eu ainda utilizasse o conceito de populismo, como era usual à época, já mostrava certo desconforto com o mesmo, assim como em outro paper sobre o tema publicado em: "Positivismo, Trabalhismo, Populismo: a Ideologia das Elites Gaúchas, in: Ensaios FEE; A Sociedade Gaúcha. Porto Alegre, FEE, n.2, 1993, p.410-421. Relendo-os, registro a recusa em confundir trabalhismo com populismo e a desconfiança quanto à utilização de "categorias" como manipulação e massas, manifestando preferência por correlação de forças políticas e classes sociais. Estas limitam concepções como 
Todavia, mostra Sérgio Monteiro que essa sequência de fases não se verificou na condução da política econômica instrumental do Governo Goulart. Posteriormente, em outro trabalho, mostramos que tampouco teria ocorrido no SGV - o que coloca em xeque a denominação de "populistas" para estes governos do ponto de vista econômico, a contar a modelagem mencionada e de mais larga utilização. ${ }^{29}$ Como afirmam Persson e Tabellini, os modelos tradicionais assentados em escolhas do tipo once-and-for-all têm dado lugar a abordagens que descrevem a condução da política econômica como o resultado da interação estratégica entre o governo - na condição de responsável pelas medidas de política econômica - e o setor privado. ${ }^{30}$ Neste sentido, o modelo de Barro presta-se mais que o de Dornbusch e Edwards para evidenciar o padrão repetitivo observado nos dois governos como o resultado de um equilíbrio no arcabouço dos chamados "jogos de política". ${ }^{31}$ Mesmo em se correndo o risco da ultrassimplificação, uma tentativa de sumariá-lo parte da existência de três fases na condução da política econômica. Na primeira, o governo propõe e executa a política de estabilização. Como esta impõe perdas, os agentes econômicos reagem e medem sua força, testando se os governantes mostram-se capazes ou não de mantê-la. Nesse momento, testa-se se o governo é do tipo "forte", e resiste às pressões, ou "fraco", e acaba gradualmente cedendo. Se o governo for deste último tipo, entra-se em uma segunda fase, de "randomização". Nesta as políticas mostram-se desencontradas, oscilatórias; decisões contraditórias pró e contra a estabilidade são tomadas alternadamente e, às vezes, quase de forma simultânea. Não raro os policymakers cedem a pressões em uma área e tendem a "compensá-las" em outra; por exemplo, afrouxam a

de "falsa consciência", pois consideram empresários e trabalhadores como segmentos ativos no desenrolar dos fatos, e não apenas passivos diante de uma autoridade carismática. Nesses trabalhos, continuava usando o conceito de "populismo", embora permeado de salvaguardas e observações paralelas, como tratar-se de objeto "contraditório" e "complexo", em contraponto às análises "simplificadoras", e ponderando que o mesmo legitimava e expressava anseios e insatisfações populares e potencialmente punha em xeque a acumulação ao atender de fato (e não apenas no plano retórico) as reivindicações sindicais (cujos líderes não eram simples "pelegos"). Leio-os, hoje, como trabalhos de transição entre a antiga literatura de tradição USP/CEBRAP e os estudos que realmente consagraram nova interpretação, como pioneiramente Angela de Castro Gomes (1988, 2002) e, posteriormente, Jorge Ferreira (1997, 2005), dentre outros autores, sem esquecer o menos lembrado mas importante trabalho de Miguel Bodea, Trabalhismo e Populismo no Rio Grande do Sul, Porto Alegre, UFRGS, 1992.

${ }^{29}$ Monteiro, op.cit.; Fonseca e Monteiro, op.cit.

${ }^{30}$ Torsten Persson e Guido Tabellini, Monetary and Fiscal Policy ; Credibility, v. 1: Cambridge MIT Press, 1995, p.1.

${ }^{31}$ Robert Barro, "Reputation in a model of monetary policy with incomplete information". In: Journal of Monetary Economics, v. 17, n. 1, 1986. 
política monetária e, a seguir, adotam uma política fiscal contracionista; mais adiante, elevam salários e, na sequência, restringem o crédito. A política $p a$ rece sem lógica ou irracional, pois dá sinais opostos quanto à prioridade pelo crescimento ou pela estabilidade. Finalmente, como não consegue compatibilizar as duas coisas, e ao ver a crise aprofundar-se e escassear sua base de sustentação, o governo acaba por ceder e entra-se em uma terceira fase, com o abandono de vez da opção pela estabilidade e com a adoção de políticas de "abertura de torneiras", como nas teorias de ciclo político oportunista. Esta terceira fase lembra o que Dornbusch e Edwards chamam de "populismo econômico", embora esta designação não seja utilizada por Barro, cujo modelo não se centra nesta questão, mas na credibilidade.

O modelo de Barro, a despeito da simplificação inerente a qualquer modelo e mesmo restrito às políticas instrumentais, ajuda-nos a mostrar pelo menos parte dos equívocos da literatura sobre o "populismo econômico" do SGV. Neste, verifica-se com clareza a existência dessas três fases - sendo que a primeira delas, de prioridade à estabilização, vai até o primeiro semestre de 1952. A segunda fase aí começa e dura pouco mais de um ano, até aproximadamente o último trimestre de 1953, quando tem início a terceira. ${ }^{32}$ Registra-se aqui o primeiro equívoco dos adeptos do "imaginário do populismo": atribuir ao SGV, em sua totalidade, o que aconteceu apenas nesta última fase - a qual durou apenas alguns meses, grosso modo, a crise política de 1954, a qual expôs as dificuldades do governo, ou, na linguagem do modelo, sua "fraqueza". Destarte, ao ignorarem a dinâmica ou o movimento da política econômica ao longo do período governamental, estes autores também cometeram um segundo equívoco: negligenciaram a primeira fase, já mencionada, com sua inequívoca tentativa de estabilização. E este abriu as portas para um terceiro: passaram a interpretar a fase de "randomização" como irracionalidade, "falta de lógica" ou equivoco dos policymakers (e até "fraqueza de caráter", no caso de Goulart). Enfim: em vez de buscarem as razões desta condução aparentemente errática da política econômica, preferiram "julgá-la": o "populismo econômico" explicaria a "hesitação" e a "ambiguidade" do governo. A circularidade da construção mental é gritante: o governo é populista porque pratica uma política econômica irracional e demagógica, e esta é irracional e demagógica porque o governo é populista. Tal como nas análises do populismo político, a adjetivação se ajusta, sem constrangimentos, ao gosto do pesquisador.

${ }^{32}$ Fonseca e Monteiro, op.cit. p. 225, 227. 
Antes de prosseguir, todavia, há que se esclarecer qual o sentido aqui atribuído a "forte" e "fraco", antítese sujeita a diversas interpretações, inclusive com a conotação certo/errado, ao gosto das teses do "imaginário do populismo". Provavelmente o entendimento de Barro não fuja à própria visão de "bastar-se a si mesmo" da ortodoxia: o governo forte seria aquele que se comportaria com o esperado pelo próprio modelo. Não obstante, como "força" e "fraqueza" não existem apenas como abstrações - e dispensada a metafísica de entendê-las como atributos inerentes ou contingentes a um ser -, parece mais apropriada a interpretação cujo sentido desvenda-se na sua própria realização como ato, o que remete ao terreno da política, qual seja, à capacidade de o governo formar/ forjar uma base de apoio capaz de dar sustentação a sua política e vencer a quebra de braço do "jogo", resistindo às pressões e impondo suas prioridades. Se o governo não for capaz de articular esta correlação de forças, entra-se em uma fase de instabilidade não apenas da política econômica; esta é, de fato, apenas uma face da instabilidade politica. É com este entendimento que se pode lançar luz a algumas hipóteses sobre a crise do SGV. Este já começa com a inconformidade e a radicalização da UDN desde as eleições, ao reclamar judicialmente um segundo turno sob o pretexto de que a vitória de Vargas com 48,7\% dos votos não atingira a maioria absoluta, exigência ao arrepio das normas legais. Esta postura perpassa por todo o período governamental e acirra-se com a campanha da PETROBRAS, com a "greve dos 300 mil" e com o "manifesto dos coronéis", que precipita a demissão de João Goulart do Ministério do Trabalho e deságua no atentado da Rua Toneleros e no suicídio de Vargas. Em uma conjuntura de forte radicalização como esta, torna-se difícil encontrar uma lógica abstrata na condução da política econômica, como se os policymakers pudessem, sem restrições, fazer uso dos instrumentais de política econômica da maneira que lhes aprouvesse. Sua racionalidade é permeada por variáveis extraeconômicas, as quais ajudam com mais pertinência detectar o sentido das decisões governamentais. Daí a hipótese de trabalho, antes mencionada, sem a qual o "imaginário do populismo" parece até possuir certo sentido como interpretação. A política econômica não se explica por si só: embora lhe seja inerente uma lógica instrumental, esta, ao contrário do que pensamos os economistas majoritariamente, subordina-se a decisões e a escolhas não decorrentes da simples opção ideológica do governo - v. g., se desenvolvimentista ou ortodoxo - nem, muito menos, de sua escolha racional por um modelo teórico, a ponto de poder ser "cobrado" por sua coerência for- 
mal. Esta é uma das razões que restringem as possibilidades de detectarem-se projetos de longo prazo, como o Nacional-Desenvolvimentismo, através de políticas instrumentais.

Diante dessas considerações, parece evidente que o SGV não preenche nem a condição-chave proposta por Dornbusch e Edwards para ser rotulado de "populista", nem a de Bresser Pereira, uma vez que o governo propôs e executou uma política de estabilização. ${ }^{33}$ Embora comprometido com a opção pelo crescimento, em seu começo, e por aproximadamente um ano e meio, a área da Fazenda assumiu como sua a "fórmula" Campos Salles-Rodrigues Alves, chegando o próprio discurso presidencial a criticar a distribuição "insensata" e apostar em investimentos norte-americanos, em evidente diálogo com o governo Truman: como sustentar, num quadro destes, o "imaginário do populismo"? Como associá-lo ao "populismo econômico", cujo fundamento é a negativa de opção pela estabilidade e pelo combate à inflação, quando justamente isto é o que foi feito? Deve-se ter presente que o abandono gradual desta prioridade, a qual se pode visualizar a partir de meados de 1952, não pode apagar nem negligenciar a op̧cão da fase inicial - a qual é oposta à "demagogia" e à "irresponsabilidade" associadas pelo referido modelo ao "populismo econômico". E, no caso, a política econômica executada não foi fortuita nem errática: tratou-se de uma escolha circundada politicamente, tanto em sua adoção como em seu afrouxamento, e não decorreu de um atributo constitutivo ("ser ou não ser" populista) nem de um ato volitivo ou "comportamento exógeno" dos governantes e dos policymakers que ocorressem à margem do quadro maior de crise em que mergulhava cada vez mais o governo.

Como pode ser observado, não se procurou aqui questionar as diferentes definições de populismo econômico adotadas pelos autores. Ao contrário, lançou-se mão do recurso metodológico de recorrer ao que a própria literatura

\footnotetext{
33 Tampouco o SGV encaixa-se na definição de populismo econômico de outros dois autores que também se voltaram ao tema, Carlos Díaz-Alejandro e Jeffrey Sachs, cujos artigos em português podem ser encontrados em: Bresser Pereira (org.), op. cit. Estes também associam populismo a ciclos de políticas "irresponsáveis" distributivas e pró-crescimento cuja insustentabilidade força a alteração para tentativas de estabilização ortodoxas, que por sua vez se mostram inócuas ou insustentáveis e impelem o retorno das primeiras. Embora haja diferenças entre os modelos de cada autor, ambos possuem em comum o ponto de partida do ciclo se dar com medidas populistas (que seria a disposição inicial do governo, e por isso tachá-lo como tal), o oposto do ocorrido no SGV, sem contar que não se configuram neste período políticas cíclicas alternadas. Talvez por isso Sachs, ao exemplificar com "episódios" o populismo latino-americano, preferiu ilustrar o Brasil com um governo mais recente, o de Sarney (1985-1988), e não o SGV, enquanto para a Argentina recorreu a um exemplo histórico: Perón (com a conjuntura 1946-1949).
} 
“considera como" - seja populista ou ortodoxo -, com o fito de se poder, $\grave{a}$ luz de seus próprios argumentos, mostrar a impropriedade de considerar-se como exemplo do fenômeno o SGV. Tal como demonstram as análises dos historiadores antes mencionados que privilegiaram as variáveis políticas para mostrar a ambiguidade e a impropriedade do conceito de populismo político para os governos de Vargas, do ponto de vista da condução da política econômica entre 1951 e 1954 também se mostra frágil sua base de sustentação. Sem contar que ambas as abordagens se interligam: ao contrário da liderança unipessoal e carismática que governa em contato direto com as massas e à margem de instâncias intermediárias, como costumeiramente o populismo político é definido por seus adeptos, o SGV foi nitidamente congressual. Quer-nos parecer que esta configuração tem sua gênese no próprio final do Estado Novo, quando da criação por Vargas dos dois partidos, Partido Social Democrático (PSD) e Partido Trabalhista Brasileiro (PTB), arquitetura política cujo suposto repousa justamente sobre o que as teses acerca do populismo questionam: a tentativa de formar uma base política ampla de sustentação do governo (e do projeto econômico que vinha sendo implementado desde 1930) dentro de um contexto de democracia. A criação dos partidos e a busca de seu enraizamento social, como é o caso do PTB nos sindicatos, querem-nos parecer não se tratar de uma simplista relação de favores com "pelegos", mas o reconhecimento da nova institucionalidade e de suas regras - ao invés de negá-las, suprimindoas ou manipulando-as, como se esperaria do protótipo do "imaginário do populismo". ${ }^{34} \mathrm{E}$ o reconhecimento de instâncias intermediárias, como as arenas partidárias e legislativas, faz parte do "varguismo" do pós-Guerra; e daí o sentido da ampla articulação política responsável por agregar desde os velhos caciques pessedistas até a esquerda nacionalista. E justamente por necessitar desta base de sustentação - cuja amplitude pode sugerir força, mas em certas conjunturas, como nas crises, mostra-se frágil - é que a política econômica não decorre de uma vontade unipessoal, nem é imposta pela autoridade carismática

\footnotetext{
${ }^{34}$ Não é objetivo deste trabalho a análise comparada entre varguismo e peronismo, mas tudo sugere que este último se situe bem mais próximo deste "protótipo", posto que menos congressual, com maior entrelaçamento entre sindicatos e estado, mais unipessoal e com forte recurso ao carisma (principalmente Evita), além de ser mais distributivista e menos comprometido do que Vargas com mudanças do modelo econômico, em direção à industrialização, conforme: Andrés Ferrari, O Peronismo: Um Fenômeno Argentino. Uma Interpretação da Política Econômica Argentina 1946-1955, Tese de Doutorado em Economia, Porto Alegre, UFRGS, 2007.
} 
à la Weber, mas precisa sujeitar-se ao "jogo" de Barro (ou, caso se prefira, às instâncias formais-legais weberianas, ou, ainda, à luta de classes de Marx).

Cabe, finalmente, assinalar que esse reconhecimento não foi apenas formal ou retórico - uma das teses mais caras ao "imaginário do populismo" é a denúncia da contradição entre o discurso e a prática de seus governantes. Ao montar um ministério com hegemonia do PSD ao assumir, e ao atribuir ao PTB apenas uma pasta (a do Trabalho, com Danton Coelho), o mesmo número legado à UDN (João Cleofas, da Agricultura), Vargas deixava clara sua predisposição a uma composição capaz de obter maioria congressual, exigência de governabilidade no presidencialismo. Não se trata de simples "conservadorismo", "ausência de compromissos", ou "ambiguidade"; $; 5$ se é preciso um rótulo-síntese, parece-nos o mais apropriado ser realismo ou pragmatismo, pois a decisão revela que o governo buscava o que seria o pré-requisito mais básico para quem assume: poder governar. Pragmatismo, no caso, nada tem a ver com o tom irônico associado à carência de compromissos ideológicos ou ausência de princípios, posto que ambos, pragmatismo e ideologia - não se pode desconhecer - sempre convivem e são necessariamente integrantes de qualquer governo, com risco de, em procedendo de outra forma, os dirigentes não conseguirem a execução de seu programa ou, no limite, mostrarem-se politicamente inviáveis, como aconteceu ao final do SGV (aliás, convivem mesmo nos regimes totalitários, onde a ideologização e a mobilização politizadora são levadas às últimas consequências). Logo, tratava-se de uma "ação social racional" inequívoca, posto que intencional e empenhada com a construção de meios adequados para viabilizar fins dentro das normas constitucionais; nada a lembrar "contato direto com as massas", "carisma", "manipulação" ou "demagogia". Da mesma forma, pode-se entender a entrada na fase de randomização não como simples fraqueza, ambiguidade ou "contradição do populismo"; "o real é o que impõe como tal”, diz a máxima hegeliana, e, no caso, nada mais longe do "imaginário do populismo" do que o "líder" submeter-se às regras do jogo e tentar maximizar suas pretensões dentro delas.

\section{A Tese da "Virada" e a Fase de "Randomização"}

Diante do propósito anteriormente assumido de analisar a política econômica do período pari passu e em contraponto à literatura sobre o mesmo, serão agora abordadas as principais medidas da "fase de randomização"

\footnotetext{
${ }^{35}$ Expressões utilizadas por D’Araújo, op.cit. p. 131-133.
} 
conjuntamente com a tese da "virada nacionalista". Pretende-se ponderar que sua relativamente longa duração, de meados de 1952 ao último trimestre de 1953, contrapõe-se claramente à interpretação segundo a qual tenha havido uma "virada" ex abrupto na orientação da política econômica.

Atribui-se a Skidmore, como já se mencionou, a tese da "virada", e merece registro por seu impacto na literatura, pois serviu de referência a praticamente todos os trabalhos posteriores. Muitos destes criticaram-no por sua divisão do período governamental dicotomicamente, embora compartilhem com outras de suas teses centrais: a "ambivalência" ou "inconsistência" da política econômica, já abordada anteriormente (como "terceiro equívoco" do "imaginário do populismo").

Embora também recorra à noção de populismo, o núcleo da argumentação de Skidmore reside na defesa de que o governo realmente teria começado "sério" e disposto a enfrentar os problemas de "curto prazo", como déficit orçamentário e no balanço de pagamentos, escassez de divisas e inflação; todavia, isto se chocava com sua prioridade de "longo prazo": a industrialização e o desenvolvimento. Vendo aprofundar o estrangulamento externo e diante do insucesso do combate à inflação, e com o aguçamento dos conflitos sociais, Vargas em 1953 teria dado uma "virada nacionalista". Nota-se que a interpretação de Skidmore não chega a negar - antes sustenta - tanto a existência de uma tentativa de estabilização como do "Nacional-Desenvolvimentismo", o qual ele denomina "fórmula desenvolvimentista nacionalista" e associa ao "ambicioso programa econômico" de Vargas. ${ }^{36}$ A maioria dos autores posteriores criticou a "virada", ponderando a necessidade de uma interpretação que captasse o período governamental como um todo, sem a dicotomia, seja no campo político, como Maria Celina D’Araújo, seja no econômico, como Lessa e Fiori, Vianna e mesmo por mim, só para citar os primeiros elaboradores desta crítica. ${ }^{37}$ Por outro lado, a argumentação desenvolvida nesse trabalho da década de 1980 foi retomada e aperfeiçoada em pesquisa mais recente, onde procurei dar mais robustez às teses segundo as quais: (a) a política econômica não fora irracional nem ambígua, mediante o recurso analítico de desvendar seu desfecho e sua racionalidade sob a mediação da correlação das forças políticas, e não em comparação a um modelo abstrato ou tipo ideal para apontarem o que seria "correto", como se mostrou na seção anterior; e (b) como também já se

${ }^{36}$ Skidmore, op. cit. p.119, 137.

${ }^{37}$ D’Araújo, op.cit. p.131-2; Lessa e Fiori, op. cit., 1984, p. 593; Vianna, op.cit. p.125; e Fonseca, op.cit., 1989, p. 359. 
adiantou, não houve mudança repentina que pudesse denotar "virada", posto que a randomização perdurou por longos meses, aproximadamente do segundo semestre de 1952 ao final de 1953. Para melhor ilustrar o ocorrido, vejamos mais de perto algumas das medidas de política econômica do período.

Um dos primeiros sintomas de que a tentativa de estabilização da "fase Campos Salles" começara a perder fôlego pode ser observado no final do primeiro semestre de 1952, com a expansão das dívidas dos estados, municípios e Distrito Federal. As despesas aumentaram com relação ao ano anterior, mas a arrecadação permaneceu praticamente a mesma em termos reais. Por outro lado, majorava a pressão por gastos públicos por parte de diversos segmentos, como crédito pelos empresários e salários pelo funcionalismo, acompanhando o movimento sindical. A tendência apontava para o crescimento do déficit do Tesouro, sendo visível a consciência dos policymakers quanto à necessidade de uma reforma tributária mais profunda para evitá-lo, a qual, além de difícil politicamente, só poderia legalmente vigorar no ano seguinte. Aos poucos o governo abrandaria a política monetária, com a expansão do crédito e liberalização das importações para atender a demanda por equipamentos, o que resultou em aumento dos investimentos e ajuda a explicar seu forte crescimento no ano. ${ }^{38} \mathrm{Sem}$ embargo, o ano de 1952 fechou invertendo os resultados da política inicial de estabilização: o PIB expandiu-se 7,3\%, depois de quatro anos com taxas de crescimento em desaceleração, e a balança comercial apresentou o saldo negativo de US\$286 milhões, o maior desde a Grande Depressão. Este se tornava o principal gargalo da fase de "randomização", a confirmar a pertinência das análises de cunho cepalino, como a de Maria da Conceição Tavares já mencionada, segundo as quais o estrangulamento externo repunha-se com o incremento da substituição de importações e era a variável mais vulnerável deste "modelo" de industrialização.

O ano de 1953 começa com o governo emitindo sinais de que não estava disposto a bancar uma política recessiva ou não tinha força para resistir às pressões: seja por um ou outro motivo, ou por ambos conjuntamente, o fato é que a política de estabilização cedia espaço como objetivo de curto prazo. A substituição de Truman pelo republicano Eisenhower na presidência dos EUA vinha dificultar ainda mais o quadro, com a suspensão do financiamento acenado por ocasião da instalação da Comissão Mista Brasil-EUA: sob a alegação de necessidade de corte nos gastos, abandonou-o como prioridade.

${ }^{38}$ Vianna, in: Abreu, op.cit. p.130. 
Todavia, esta decisão do governo norte-americano refletia apenas uma face da mudança de sua diplomacia em prol de uma linha mais dura com relação a governos entendidos como "dúbios" ou "nacionalistas", como os de Vargas e Perón. Estes não seriam tolerados. Assim, ao contrário da época do Estado Novo, cuja divisão do mundo capitalista em dois blocos possibilitou uma política de barganha, no contexto de Guerra Fria pouco espaço restava para isto. Dentre as prioridades da política externa norte-americana não estava a América Latina, mas a reconstrução européia e japonesa e a Guerra da Coréia. Todavia, os US \$300 milhões eram indispensáveis não só para levar adiante os projetos sugeridos pela Comissão como seriam preciosos para dar uma folga ao balanço de pagamentos, diante do agravamento da crise cambial e da escassez de moedas conversíveis. Se o bom senso poderia sugerir ceder às pressões norte-americanas, por outro lado o sentimento nacionalista se aguçava com a campanha pela nacionalização e monopólio do petróleo, o que resultou na criação da PETROBRAS, ao mesmo tempo em que as greves se multiplicavam com demandas por aumento de salários.

Pressionado por um lado e por outro, o governo inclinava-se pelo atendimento às demandas sindicais e o discurso presidencial aprofundava seu tom nacionalista. No entanto, em direção oposta, a lembrar a "randomização", neste mesmo momento, em janeiro de 1953, surge a Lei do Mercado Livre (Lei 1.807), cujo propósito era atrair capital estrangeiro via liberdade cambial e afrouxamento dos critérios para reinvestimentos. Não obstante, e a mostrar que não abriria mão dos compromissos industrializantes e desenvolvimentistas, mantinha a política de segmentar tanto as importações por faixas de acordo com a essencialidade dos bens, como as exportações em categorias conforme o peso do produto na pauta, de forma a incentivar sua diversificação. Assim, sem eliminar o controle quantitativo das importações, a administração do câmbio começava a ser feita mais através de desvalorizações cambiais de acordo com as faixas em que os bens eram enquadrados (duas para as importações, cinco para as exportações). Na prática, ficava estabelecido um sistema de taxas múltiplas de câmbio o qual buscava compatibilizar uma saída para a crise do balanço de pagamentos com o crescimento econômico, pois privilegiava a importação de bens de capital e insumos essenciais, administrando ganhos e perdas decorrentes da crise cambial segundo um critério nitidamente político e pró-desenvolvimento. A Lei do Mercado Livre sinaliza claramente a situação delicada do governo: poderia ceder em parte para equilibrar as contas 
públicas, o que abria espaço a uma política stop and go executada em 1953, mas não transigiria com relação a seus compromissos desenvolvimentistas e sua aliança com os sindicatos trabalhistas.

Isto fica claro quando em março de 1953 começou em São Paulo um movimento grevista, o qual, paulatinamente, espalhou-se pelo país e configurou a maior greve até então: a "greve dos 300 mil". Apesar da pressão da grande imprensa em favor de uma atitude mais dura, o governo agia no sentido de impedir sua radicalização, ao acenar mais com negociação do que com repressão, atitude interpretada como fraqueza ou condescendência. Para os políticos radicais da UDN - a chamada "banda de música", pelo barulho que fazia - ficava evidente que o governo incentivava o movimento grevista para acirrar os ânimos contra os Estados Unidos, em uma clara atitude fomentadora da anarquia e da luta de classes de inspiração comunista.

Assim, com um olho no cravo e outro na ferradura, ou seja, preocupado com o agravamento cada vez maior dos déficits públicos e do balanço de pagamentos e com o crescimento da inflação, ao mesmo tempo em que os movimentos sociais e sindicais se fortaleciam e radicalizavam, o governo em junho de 1953 decidiu por uma reforma ministerial. O convite para João Goulart ocupar o cargo de Ministro do Trabalho é dos argumentos mais fortes da interpretação da "virada nacionalista". Presidente nacional do PTB, Goulart disputava com Vargas o posto de político mais odiado pela oposição udenista (título que, a partir daí, lideraria disparado, só rivalizando com Leonel Brizola no início da década de 1960). Cabia a ele a negociação com os sindicatos e desde a campanha do queremismo mostrara, aos olhos dos políticos tradicionais, nítidas "inclinações populistas", como receber os líderes sindicais - os "pelegos", na linguagem oposicionista -, com eles dialogar e acertar decisões e propostas, muitas das quais se tornavam bandeiras partidárias. Sua habilidade no tratamento inclusive com a esquerda mais radical causava surpresa e repulsa: afinal, não era isso o que se esperava de um grande fazendeiro de São Borja, conquanto restasse indagar o que haveria de inusitado nesse comportamento por parte de alguém cujo papel era de líder trabalhista. ${ }^{39}$ Mas a decisão de Vargas não consistia apenas um jogo de cena, porquanto reflete a

${ }^{39}$ Dentre os trabalhos que analisam a atuação de Goulart neste período, ver: Jorge Ferreira, O Imaginário Trabalhista, Rio de Janeiro, Civilização Brasileira, 2005, cap. 2; Marieta de Moraes Ferreira (org.), João Goulart: entre a Memória e a História, Rio de Janeiro, FGV, 2006; e Ângela de Castro Gomes e Jorge Ferreira, Jango: as Múltiplas Faces, Rio de Janeiro, FGV, 2007, cap. II. 
clara decisão de não abrir mão de sua base sindical e de negociar com os movimentos grevistas. Afinal de contas, como falar em trabalhismo se a repressão substituísse a negociação?

Todavia, o desencadear dos acontecimentos mostra que a mudança ministerial não significou nenhuma "virada". Primeiro, porque a atitude de Vargas seja com relação ao movimento grevista seja com relação ao nacionalismo (PETROBRAS) não representou qualquer alteração substantiva ou reorientação de política, pois a entrada de Jango, como era conhecido o ministro, apenas mantinha e explicitava a opção pela postura pró-negociação que já vinha sendo praticada. Segundo, porque, ao lado deste, convidou Osvaldo Aranha para o Ministério da Fazenda, em substituição a Lafer. Decisão típica não da "virada", mas da "randomização", a qual demonstra sobretudo realismo político: Aranha era o político brasileiro mais conhecido e respeitado nos Estados Unidos e na comunidade financeira internacional, peça importante para representar o governo brasileiro no exterior e encaminhar suas reivindicações.

A decisão mais importante de Aranha para enfrentar o problema cambial foi a Instrução 70 da SUMOC, de outubro de 1953. Esta, apesar de representar uma tentativa de estabilização e receber manifestações de apoio até de segmentos tradicionais de oposição a Vargas, como importadores e exportadores, demonstra que o governo mantinha seus compromissos com o que se denominaria posteriormente de Nacional-Desenvolvimentismo. E, mais uma vez, que não havia incompatibilidade a priori entre este e a busca por estabilidade, além de reiterar que o SGV não se enquadra na definição de "populismo econômico" de Dornbusch e Edwards. A leitura da Instrução mostra todo o cuidado de caminhar num fio de navalha e costurar uma tentativa voltada a reverter os problemas cambiais sem comprometer o crescimento econômico e o projeto de industrialização. De um lado, a Instrução trouxe o monopólio cambial ao Banco do Brasil e introduziu o sistema de leilões de câmbio em substituição aos licenciamentos. A administração política do câmbio continuava ao estabelecerem-se cinco faixas para importação, de acordo com a essencialidade, para as quais haveria alocação específica de montantes de divisas a serem leiloadas. Permanecia no papel um dólar oficial fixo (Cr\$18,50), mas na prática este era acrescido de um ágio decorrente do leilão. Ou seja, para todos os efeitos houvera uma desvalorização cambial, pois o preço do dólar aumentara em todas as faixas, embora mais para os bens considerados "menos essenciais" (encareceram-se significativamente as importações destes, pois cerca de $80 \%$ das divisas leiloadas destinavam-se às três primeiras faixas). 
Como economia e política se entrosam, ou seja, que segmentos se mostraram contra e a favor da nova política cambial? Como significava um rompimento com o câmbio fixo do Acordo de Bretton Woods, o FMI criticou a medida. Já o empresariado dividiu-se: alguns industriais criticaram, mas exportadores e importadores aplaudiram-na - aparentemente contrariando a "lógica" de sustentação política do governo. Para aqueles que facilmente tinham acesso aos licenciamentos, como os líderes empresariais mais influentes, a Instrução 70 viera aumentar custos com o câmbio mais alto, daí por certo preferirem o sistema antigo - o qual, infelizmente, acabara não por simples opção dos policymakers, mas pelo aprofundamento da crise. Mas este não era o caso de muitos pequenos e médios empresários - da indústria, da agricultura e do comércio - dependentes de importações. Por outro lado, o câmbio também se desvalorizaria para o exportador, representando certo alívio ao setor que há anos sentia-se prejudicado com a valorização real do dólar decorrente da inflação gradual do cruzeiro associada à taxa cambial fixa: também de forma discriminada, a Instrução definiu duas faixas: um bônus sobre o dólar oficial de $\operatorname{Cr} \$ 5,00$ para as exportações de café e de $\operatorname{Cr} \$ 10,00$ para os demais produtos medida que vai na mesma direção impressa por Vargas já na década de 1930 ao setor: a diversificação das exportações com o fito de diminuir o peso do café na balança comercial. ${ }^{40}$ Embora em tese se possa afirmar que exportadores e importadores tenham interesses imediatos opostos com relação à política cambial, a Instrução 70 conseguiu o tento raro de contentar os dois lados: os exportadores comemoravam o bônus e o descongelamento do dólar e os importadores, os leilões. Diante da gravidade da crise e da impossibilidade de obtenção de licenciamentos na prática, a opção de pagar mais caro nos leilões mostrava-se preferível à de inviabilizar o negócio. Mas para todos, inclusive para os industriais, a Instrução 70 trouxe um alento: o aceno para a possibilidade de encaminhar solução para um problema que se arrastava há anos. Até para o governo, pois a diferença entre o ágio obtido nos leilões e o bônus pago

\footnotetext{
${ }^{40} \mathrm{Na}$ década de 1930, utilizara-se outro instrumento: a adoção de uma taxa de câmbio única e desvalorizada. Entendia-se a desvalorização cambial como necessária para dar certo fôlego ao setor exportador diante da crise, mas temia-se a consequência de levar a um aumento indesejado na oferta de café, como na Primeira República, e majorar ainda mais a superprodução. O governo, então, aumentou os impostos sobre o próprio setor cafeicultor, inicialmente de $20 \%$ sobre as exportações e, em seguida, sobre cada novo cafeeiro plantado no estado de São Paulo. Não havia, portanto, taxas múltiplas de câmbio, mas essa medida ajudou a diversificar a pauta de importações e controlar a longo prazo a oferta de café. Ver: Fonseca, op. cit., 1989, cap. 4.
} 
aos exportadores acima do dólar oficial representou uma nova fonte de receita para o setor público, importantíssima em conjuntura de déficit orçamentário e de difícil sustentação política para aumentar impostos. Este "subproduto" da Instrução por certo contribuiu para a longa vida do sistema de leilões de câmbio, até o governo Jânio Quadros. Nem mesmo Eugênio Gudin, Ministro da Fazenda de Café Filho, e famoso por suas diatribes ao desenvolvimentismo, à heterodoxia e à industrialização, teve coragem de extingui-lo. Como se vê, o pragmatismo sobrepujar a ideologização não era privilégio de Vargas, apesar de seu caso ser mais lembrado pela literatura...

Entretanto, se havia certo otimismo quanto às expectativas futuras, não se esperavam resultados imediatos. Como sói acontecer com alterações nas políticas monetárias e cambiais, faz-se necessário um tempo de maturação para se colherem frutos. Enquanto isso, a inflação se acelerava e alcançava cerca de $20 \%$ ao final de 1953 , porcentagem igual ao crescimento das despesas da União no ano. Avolumavam-se os atrasados comerciais e a maior expansão anual, em cerca de $90 \%$, ocorrera com o crédito ao Tesouro por parte do Banco do Brasil, a evidenciar a política monetária expansionista praticada. ${ }^{41}$ Aranha parecia disposto a voltar à "fase Campos Salles", se necessário fosse (ao que consta, a "fórmula" Campos Salles-Rodrigues Alves fora sugestão dele a Lafer, no início do governo); mas não havia mais condições políticas para isso nem o presidente mostrava-se inclinado a esta mudança de rota. $\mathrm{O}$ quadro agravou-se com a divulgação de um estudo do Ministério do Trabalho, vazado à imprensa, com a proposta para apreciação presidencial de aumento de $100 \%$ para o salário mínimo. Fato inusitado: gradualmente o palco dos acontecimentos da área econômica, para onde normalmente se voltam as atenções, não era mais o Ministério da Fazenda, mas o do Trabalho. Tudo sugere que Jango contava com o aval de Vargas, pois passou a defender energicamente a proposta de aumento, enquanto a grande imprensa e as associações patronais majoritariamente a rejeitavam. O clima de radicalização começava a ganhar proporção nunca vista; sem centro no campo político com capacidade de mediação, a divisão do país em dois blocos antecipava 1964. Era o fim da "randomização" e o início do fim do SGV.

A aproximação da UDN com os quartéis vinha de longa data: desde o final do Estado Novo, quando Vargas fora derrubado e sufocado o "queremismo". Com a crise, retomava agora seu ímpeto e em janeiro de 1954 o

${ }^{41}$ Vianna, in: Abreu, op.cit. p.142. 
“Manifesto dos Coronéis” exigia a demissão de Goulart do ministério. Vargas pareceu inicialmente implacável às pressões, mas, no mês seguinte, Goulart deixava o cargo. Tudo parecia sugerir a vitória fora das forças oposicionistas e o movimento sindical voltava a organizar-se possivelmente para nova ofensiva. Todavia, Vargas surpreende e, em $1^{\circ}$ de maio, anuncia oficialmente o aumento de $100 \%$ do salário mínimo - como a mostrar quem, de fato, governava. O clima inverte-se: os que comemoravam em um dia sentem-se derrotados no outro e vice-versa. Sem contar que juntamente com o aumento propunha-se verdadeiro "pacote" para a área trabalhista e previdenciária, possivelmente o último conjunto de medidas para ampliar direitos sociais até a Constituinte de 1988: extensão de benefícios previdenciários a várias categorias de trabalhadores e seus dependentes, inclusive profissionais liberais autônomos, domésticas e trabalhadores rurais; extensão, a estes últimos, através da Carteira do Trabalhador Rural, de estabilidade, duração de jornada de trabalho e proteção ao trabalho da mulher e do menor; fim do limite do valor das pensões, tornando-as proporcionais aos salários; aposentadoria aos 55 anos de idade para atividades "penosas e insalubres"; criação do auxílio-matrimônio; e, finalmente, participação dos trabalhadores na gestão dos institutos de aposentadorias e pensões. ${ }^{42} \mathrm{~A}$ maior parte destas medidas não foi posta em prática, até porque o governo só duraria pouco mais de três meses.

\section{A Ortodoxia e o Nacional-Desenvolvimentismo como Fiç̧ão}

Finalmente, cabe abordar a terceira corrente, a qual advoga que a política econômica não fora nem populista nem desenvolvimentista, mas ortodoxa e conservadora. Em contraponto, trar-se-á à liça a que interpreta o SGV como afirmação do Nacional-Desenvolvimentismo, posto que ambas dialogam e a crítica a uma ocorre pari passu à afirmação da outra. A escolha dos últimos meses do governo para conjuntamente abordá-las resulta de uma opção metodológica: a radicalização do período manifesta-se tipicamente no debate posterior da literatura.

Como já se mencionou, os trabalhos pioneiros a defender, de uma forma mais acabada, a ortodoxia da política econômica dos anos 1951-1954 foram os de Lessa/Fiori e Vianna. Em uma primeira objeção, registra-se que ambos parecem generali:ar para todo o período o que teria ocorrido nos primeiros meses do governo, quando se pode detectar com mais nitidez a opção pela estabilização. Todavia,

${ }^{42} \mathrm{O}$ conjunto de medidas encontra-se arrolado em: Fonseca, op. cit., 1989, p. 450. 
ambos os autores vão além: (a) admitem como pressuposto a incompatibilidade entre política de estabilização e Nacional-Desenvolvimentismo (este denominado por Lessa/Fiori sintomaticamente de "nacional-populismo"), e assumem que ambos, em qualquer circunstância, são a priori excludentes; e (b) negam a existência de um projeto de industrialização por parte do governo; suas análises, então, extravasam o âmbito das políticas econômicas instrumentais para um questionamento mais fundo sobre o significado histórico do varguismo e do "populismo", pois chegam a apregoar a inexistência deste último por entenderem que o governo era conservador, nada tinha de nacionalista, pró-indústria ou favorável aos trabalhadores. Destarte, causa espécie a quem está acostumado com a memória histórica de Vargas e do trabalhismo - e principalmente com o radicalismo político da UDN e da polarização que precedeu o golpe de 1964 - tanto a afirmação de Vianna de que não conseguira detectar uma política econômica comprometida com a industrialização no SGV, como a de Lessa e Fiori segundo a qual "não encontramos evidências consistentes, nos planos das intenções e objetivos e, muito menos, no das políticas realmente executadas" de que no período teria havido um projeto governamental de desenvolvimento "nacional autônomo e popular", capitaneado pelo Estado e centrado na industrialização e na modernização agrícola (em outras palavras, o projeto Nacional-Desenvolvimentista). ${ }^{43}$

Quanto ao plano das "intenções e objetivos", com a devida vênia, o assunto parece resolvido: basta consultar os discursos, pronunciamentos, entrevistas e relatórios de Vargas do período, abundante material que não deixa dúvidas a respeito. E é justamente neste "plano" que a pesquisa empírica mais avançou e permite antever com mais nitidez a existência do projeto, posto que a análise das políticas efetivamente implementadas sempre deve levar em consideração que as mesmas nem sempre são as pretendidas ou preferidas pelos governantes, pois circundadas por inúmeros fatores, desde necessidades impostas pela conjuntura internacional até pressões de ordem política.

Já com relação ao "plano das políticas realmente executadas", tanto trabalhos coetâneos de autores, como de Draibe, até mais recentes, como de Bastos, exaustivamente embasam e demonstram a implementação de medidas por parte do Estado cujo propósito inequívoco se centrava na industrialização acelerada e na modernização agrícola, a configurar, nas palavras da primeira, "um projeto político e econômico de desenvolvimento do capitalismo no

${ }^{43}$ Vianna, op. cit.; Lessa e Fiori, op.cit. p. 575. 
Brasil mais profundo e complexo, mais abrangente, ambicioso e integrado que aquele que se delineara ao final da década de 1930". E a despeito de, em certas ocasiões, como nos meses iniciais do governo, terem-se lançado medidas voltadas à estabilização, no pensamento de Vargas, pelo menos a partir da década de 1930, sempre predominou o entendimento quanto à possibilidade de compatibilizar crescimento econômico com inflação. Nas palavras de Bastos: "O combate à inflação deveria ser realizado em duas frentes, simultâneas e complementares: ampliar a produção com apoio decidido das políticas cambial e de crédito, e assegurar equilíbrio orçamentário". ${ }^{44}$ Estas palavras grifadas remetem justamente ao que caracteriza a heterodoxia da época na América Latina, qual seja, o pensamento cepalino: não se negava a limine a necessidade de políticas contencionistas (seja, por exemplo, para evitar déficits crônicos no orçamento público e no balanço de pagamentos, ou para o enfrentamento de processos inflacionários), mas buscava-se sua compatibiliæação com aumento da produção - ou, pelo menos, estabilizar minimizando os prejuízos à produção e ao desenvolvimento. Como se sabe, a ortodoxia econômica nunca compactuou com esta possibilidade (inflação zero é dogma intransponível, e a ironia monetarista da época consagrou a frase segundo a qual não existe pequena inflação, tal como "pequena gravidez"). Por conseguinte, as dificuldades de implementação do Nacional-Desenvolvimentismo como projeto, com as adversidades da conjuntura, não podem ser interpretadas como ambiguidade nem como hesitação-e, muito menos, como sua inexistência. A chamada fase de "randomização" mostra claramente a tentativa do governo de levá-lo adiante mesmo diante de um quadro abstruso (seja por opção ideológica seja por tentar maximizar sustentação política, ou por ambas ao mesmo tempo).

Por isso se deve considerar a hipótese de que não há incompatibilidade entre governos tidos como adeptos do Nacional-Desenvolvimentismo, em certas conjunturas e diante de certas circunstâncias, implementarem políticas de estabilização que impliquem diminuir o ritmo de crescimento a curto prazo. Obviamente estes governos não podem nem abolir o ciclo econômico nem desconhecer os problemas conjunturais e a necessidade de enfrentá-los, com o risco de comprometerem ainda mais o projeto de desenvolvimento acelerado no longo prazo. ${ }^{45}$ Não há como se exigir deles uma politização da economia

${ }^{44}$ Sônia M. Draibe, Rumos e Metamorfoses: Estado e Industrialização no Brasil, 1930-1960, São
Paulo, Paz e Terra, 1986; Pedro Paulo Zahluth Bastos, "Qual o Projeto Econômico Varguis-
ta?", Texto para Discussão, IE/UNICAMP, maio 2009, p. 19 (grifos meus).
${ }^{45}$ Não por acaso, em 2004, Giovanni Arrighi, surpreso com as resistências na América Latina 
a ponto de ignorarem as restrições impostas emergentes em conjunturas (das quais não escapam nem os governos socialistas). Mas, mesmo assim, a forma com que a política econômica é formulada permite muitas vezes que seus "compromissos maiores" possam ser antevistos. No caso do SGV, o mais importante, por exemplo, na Instrução 70, não é a desvalorização cambial - medida mais visível assinalada pelos críticos como "prova" de que o governo havia abandonado o ideário Nacional-Desenvolvimentista ao encarecer os insumos e bens de capital necessários à indústria e à agricultura. Relevante é assinalar que, após várias tentativas frustradas de enfrentar os problemas da inflação, do balanço de pagamentos e do orçamento público sem alterar o câmbio, depois de dois anos e meio de governo só viu os mesmos aprofundarem-se, o que inviabilizava o próprio projeto de desenvolvimento.

Que alternativas restavam sem alterar o câmbio? A "sabedoria econômica convencional" aconselharia, neste caso: (a) a fixação de uma nova taxa de câmbio, com elevação abrupta do dólar, de modo a contrair importações e aumentar exportações, diminuindo o déficit nas Transações Correntes; ou: (b) num sistema de taxas flexíveis, deixar as forças de mercado atuarem de modo a alcançar o novo equilíbrio. Em ambos os casos, a desvalorização cambial traria prejuízos muito maiores ao setor produtivo nacional. O governo, então, optou por uma terceira alternativa: estabeleceu o monopólio cambial no Banco do Brasil e introduziu o sistema de leilões, de forma a repartir os custos desigualmente entre os diferentes segmentos, privilegiando os bens

às políticas estabilizadoras, como se fossem algo "de direita", argumentou: "A irresponsabilidade financeira não ajudará ninguém e não ajudará os países do Sul, só os tornará mais endividados", in: Folha de São Paulo, Caderno Mais!, 29/06/2009, p.3. Problema semelhante ocorreu por ocasião do Governo Goulart, quando coube aos ministros San Thiago Dantas e Celso Furtado a responsabilidade do acompanhamento e execução do Plano Trienal e da política econômica. Ambos eram afinados com as teses nacionais-desenvolvimentistas, mas entenderam que, diante da conjuntura, fazia-se necessário conter o déficit público e as emissões do Tesouro, bem como frear os aumentos salariais do setor público. A acusação de que ambos haviam traído seus ideais ao assumir o governo foi largamente explorada à época, inclusive por membros do PTB, como Leonel Brizola. Furtado, particularmente, respondia mostrando que sem haver um mínimo de estabilidade todos os investimentos e reformas previstos pelo plano ficariam comprometidos. Ou seja: os críticos raciocinavam com um mundo ideal onde não havia restrições orçamentárias e cambiais, como se a questão se restringisse à "vontade política" e pudesse a equipe econômica fugir à responsabilidade de enfrentar a inflação e a crise do balanço de pagamentos, e levar o país à inadimplência. Irrealismo político, pois qual elite dirigente pretenderia quebrar o Estado? A posição de Furtado deixa claro qual a proposta do Nacional-Desenvolvimentismo: não é crescer sempre e a qualquer custo; em determinadas conjunturas, diminuir o ritmo do crescimento com vistas à estabilidade é o melhor caminho para preservar o crescimento de longo prazo. 
considerados "essenciais" por seu projeto político. Com uma tacada encarecia os bens não essenciais, fomentando sua substituição de importações, e barateava relativamente os essenciais; e, em adição, criava uma receita adicional ao governo com a diferença da conta "ágio menos bônus". Esta tentativa de buscar a estabilização sem perder a "batalha da produção", como Vargas se referia em seus discursos, revela outra forma de administrar a crise, e diversa da que criticaria no Governo Dutra, a quem atribuía a prioridade pelo arrocho fiscal e monetário. Pode-se ilustrá-la com outros exemplos, inclusive de seu governo anterior, especialmente no Estado Novo, quando, em 1944, o Imposto sobre Lucros Extraordinários, com o qual se pretendia ao mesmo tempo combater a inflação e criar um fundo compulsório para canalizar os lucros para financiar reposição de capital fixo e novos investimentos no futuro. Através deste mecanismo, taxavam-se excedentes que poderiam ser destinados a consumo correntes para reorientá-los à compra de Certificados de Equipamentos, os quais os empresários poderiam adquirir pelo valor correspondente ao dobro do imposto devido com rendimentos de $3 \%$ ao ano e passíveis de resgate em moeda internacional, desde que importassem bens de capital segundo prioridades estabelecidas pelo governo. ${ }^{46}$

Em síntese: parece totalmente impróprio pretender criticar a existência do projeto Nacional-Desenvolvimentista com base na adoção de políticas de estabilização, ortodoxas ou não, por parte dos governos, ou denunciá-los como "conservadores" ou "dúbios", como se os mesmos devessem ignorar os problemas macroeconômicos conjunturais em nome de uma coerência abstrata com um modelo ideal de comportamento. Faz-se mister ter presente que, do ponto de vista metodológico, Nacional-Desenvolvimentismo e políticas de estabilização possuem diferentes escopos; como categorias, expressam fenômenos que não se excluem nem a priori nem historicamente: o primeiro aponta para um projeto de longo prazo (muito além de um "plano de governo" ou de execução de metas planejadas pelos policymakers), enquanto as segundas dizem respeito ao manejo das políticas econômicas instrumentais (monetárias, cambiais e fiscais). Não se nega a relação entre ambos, como evidenciam os exemplos da Instrução 70 da SUMOC e o Imposto sobre Lucros Extraordinários; mas esta relação não é absoluta nem necessária. Não fossem todas as razões já expostas, deve-se ter presente que a ação do governo transcende a estas políticas econômicas instrumentais. No caso, as leis e demais medidas nas áreas do trabalho, da

${ }^{46}$ Bastos, op.cit. p. 7, 19. 
educação e da própria economia, como na política industrial e agrícola, além da criação de instituições como ministérios, órgãos, institutos e conselhos, vêm muito mais robustecer as evidências de um projeto do que o manejo de variáveis como taxas de câmbio e de juros, necessariamente condicionadas pelas restrições externas e internas, fatores limitantes em sua implementação, as quais na prática muitas vezes ofuscam o analista voltado a decifrar sua intencionalidade. $\mathrm{O}$ escopo entre as diferentes políticas torna-se visível porquanto se materializam em ações estatais com tempos, prazos, razões e motivações não coincidentes e, às vezes, até conflitantes, o que se explicita, na práxis cotidiana, como contradição. Um projeto é mais que um plano de governo ou um conjunto de metas, embora possa nestes se materializar; supõe uma ação orientada, ou práxis consistente com determinada Weltanschuung. É muito mais amplo e abrangente, menos instrumental e mais teleológico, menos reativo e mais valorativo. Na linguagem corriqueira: menos conjuntural ou de curto prazo e mais estrutural ou de longo prazo. E é tão-somente neste último que pode ser percebido em seu sentido, na direção que pretende imprimir à economia e à sociedade, com propostas profundas e coerentes entre si nas mais diversas áreas, muito além das variáveis estritamente econômicas, como educação, transportes, saúde, direitos sociais, relação capital/trabalho e cultura, por exemplo. Exige, portanto, um conjunto de instituições com o qual contará para sua viabilidade e implementação (como os órgãos criados por Vargas desde a década de 1930 e as reformas institucionais do PAEG, no governo Castelo Branco, por exemplo).

Com isso em mente e sem pretender definir projeto como tipo ideal nem, muito menos, restringi-lo a recurso metodológico para ordenar mentalmente um todo complexo, mas entendendo-o em sua historicidade como um conjunto de politicas efetivamente implementado, parece indiscutivel que desde 1930 o governo brasileiro começou a pôr em prática medidas que não podem ser atribuídas ao acaso ou a meras reações aos percalços da conjuntura. Desde logo há a manifestação explícita por parte dos governantes, que se avoluma e ganha consistência ao longo da década e, principalmente, no período da II Guerra, de superação do modelo agroexportador através de medidas para materializar como alternativa a industrialização e a diversificação da produção agrícola e da pauta de exportações. Já na década de 1930 o projeto torna-se perceptível com o aparecimento de novas leis, como as do trabalho, a reforma tributária de 1934, os Códigos de Minas e de Águas, ambos também de 1934; novos órgãos voltados a incentivar 
a produção e regulá-la, como os institutos do Café, do Açúcar e do Álcool, do Pinho, do Mate e da Borracha, dentre outros; para racionalizar o crédito, como a Carteira de Crédito Agrícola e Industrial do Banco do Brasil, de 1937; e, finalmente, com a intervenção direta do governo na produção industrial, com a criação da Companhia Siderúrgica Nacional, com a Usina de Volta Redonda, e com a Companhia Vale do Rio Doce, no início da década de 1940. Não cabe aqui enumerar exaustivamente os órgãos criados no SGV em continuidade a esta política, mas registra-se o fato já mencionado da criação da Assessoria Econômica, uma inovação, já que especializa parte da equipe econômica no planejamento de longo prazo, a antecipar um futuro ministério para a área. ${ }^{47}$ Junto a esta, criaram-se comissões para tratar temas específicos (como de Desenvolvimento Nacional, de Coordenação e Desenvolvimento de Transportes, de Abastecimento e Preços, de Intercâmbio Comercial com o Exterior, e de Revisão de Tarifas Aduaneiras, dentre outras) e para propor planos nacionais (para transportes, como tratores, caminhões e automóveis; para energia, como voltado ao petróleo, à eletrificação e ao carvão). Na área financeira e do crédito, criaram-se o Banco de Crédito do Amazonas e o Banco do Nordeste do Brasil, além do Banco Nacional de Desenvolvimento Econômico - BNDE. Este, juntamente com a PETROBRAS e a ELETROBRAS, tornar-se-ia um dos órgãos-símbolo do Nacional-Desenvolvimentismo brasileiro.

Essas medidas não são fragmentárias nem reativas; o elo que as une é apontar para um devir que deveria ser construído: o desenvolvimento nacional. Como afirma pertinentemente Bastos: "Essa tarefa era custosa financeira e politicamente, e envolvia uma vontade política nada trivial, nem automática". ${ }^{8}$ Repousava sob o entendimento de que esta construção não adviria por forças espontâneas ou pelos mecanismos de mercado; o Estado deveria ser o agente indutor das mudanças. Assentava-se na consciência de que havia um atraso do país, mais tarde denominado subdesenvolvimento: este não se devia a uma questão racial ou climática, ou a qualquer determinismo geográfico ou biológico, mas a uma situação histórica: o fato de o país, desde suas origens, voltar-se à agricultura de exportação, tornara-o dependente na

${ }^{47}$ Para uma lista mais completa desses órgãos na década de 1930 e no Estado Novo, ver: Pedro Cezar Dutra Fonseca, op.cit., 2003, p.133-148. No Segundo Governo Vargas: do mesmo autor, op. cit., 1989, p. 366. Sobre a Assessoria Econômica de Vargas, uma referência recente obrigatória é: Renata Belzunces dos Santos, A Assessoria da Presidência da República: Contribuição para a Interpretação do Segundo Governo Vargas (1951-1954), Dissertação de Mestrado em História Econômica, Campinas, UNICAMP, 2006.

${ }^{48}$ Bastos, op.cit. p. 4. 
ordem econômica internacional e o caminho para a superação viria pela industrialização através da substituição de importações e pela diversificação da produção agrícola, com prioridade ao mercado interno. Tratava-se, portanto, de um projeto de desenvolvimento capitalista, mas não conservador, posto que visava fundamentalmente à transformação de marcos estruturais da sociedade brasileira: de agrária para industrial, de rural para urbana, de atrasada para desenvolvida, de subordinada internacionalmente para mais autônoma, de exportadora para voltada ao mercado interno, de altamente especializada no mercado internacional para diversificada, e, finalmente, de renda concentrada para mais bem distribuída.

Obviamente que estas transformações - de vulto nada desprezível no contexto latino-americano - não significavam parte da caminhada em direção ao socialismo, para desgosto de parte de seus opositores, nem mesmo como uma etapa de preparação a ele, como pensavam outros segmentos da esquerda da época. Mas traziam consigo também a proposta, então expressa no trabalhismo, de uma sociedade mais justa e equilibrada, em consonância ao que Bobbio define como "esquerda": "mais igual". ${ }^{49}$ Sua utopia residia ao atribuirse o papel de sujeito da história e, em decorrência, propor-se a construir nova sociedade, com base em políticas de desenvolvimento acelerado capitaneadas pelo Estado - sonho compartilhado pelos críticos do capitalismo, com exceção dos anarquistas, desde a Revolução Industrial. Um dos maiores equívocos de parte de seus críticos é querer definir o Nacional-Desenvolvimentismo como "deveria ser", ou como gostaria que fosse, em vez de limitar-se a buscar entender como historicamente se apresentou, com suas propostas de envergadura, suas contradições, seu pragmatismo e utopia, como elementos e facetas necessariamente integrantes de todo projeto político. Por exemplo: como tal, o projeto não excluía o capital estrangeiro: seu nacionalismo, mesmo que por vezes de retórica exacerbada, não significava xenofobia, mas limitava-o a determinadas áreas e propunha-se a regulamentá-lo - o que potencialmente representaria choque de interesses, como por ocasião da Comissão Mista Brasil-Estados Unidos com Eisenhower. O projeto nacional era produzir aço e resguardar os minérios e o petróleo sob o controle nacional, mesmo que recorresse a tecnologia e financiamento externo, como procedeu Vargas na famosa barganha entre Estados Unidos e Alemanha para a construção da

${ }^{49}$ Norberto Bobbio, Direita e Esquerda; Razões e Significados de uma Distinção Política, São Paulo, UNESP, 1995. 
Companhia Siderúrgica de Volta Redonda. Como afirma Bastos: "Contraposto à ideologia ufanista tradicional, o nacionalismo econômico varguista defendia a intervenção para o desenvolvimento, ou seja, não era apenas nacionalismo, mas nacional-desenvolvimentismo". ${ }^{50}$

Destarte, negar sua existência ou tratá-lo como mera expressão do conservadorismo ou do populismo manipulador leva à depreciação de um fenômeno de maior envergadura, dos poucos cujo alcance e desdobramentos acenavam para alternativa diferente da forte concentração de renda e do autoritarismo impregnados na história latino-americana. A aguerrida oposição à época do $S G V$ é a mais concreta denúncia histórica de existência. Afinal, contra o que e contra quem exatamente se opunham ferozmente políticos, empresários, clero, civis e militares tão bem representados pela UDN e vitoriosos em 1964?

Infelizmente esses entenderam com mais precisão o significado histórico do Nacional-Desenvolvimentismo e do trabalhismo que boa parte dos intelectuais que se debruçaram sobre eles como objeto de pesquisa e análise.

${ }^{50}$ Bastos, op.cit. p. 2. 